\title{
Distribucija imovine kućanstava u Hrvatskoj
}

\section{Kunovac, Marina}

Source / Izvornik: Odabrani prijevodi, 2020, 11, 1 - 32

Journal article, Published version

Rad u časopisu, Objavljena verzija rada (izdavačev PDF)

https://doi.org/10.3326/op.54

Permanent link / Trajna poveznica: https://urn.nsk.hr/urn:nbn:hr:242:443654

Rights / Prava: Attribution-NonCommercial-NoDerivatives 4.0 International/ImenovanjeNekomercijalno-Bez prerada 4.0 međunarodna

Download date / Datum preuzimanja: 2023-04-26
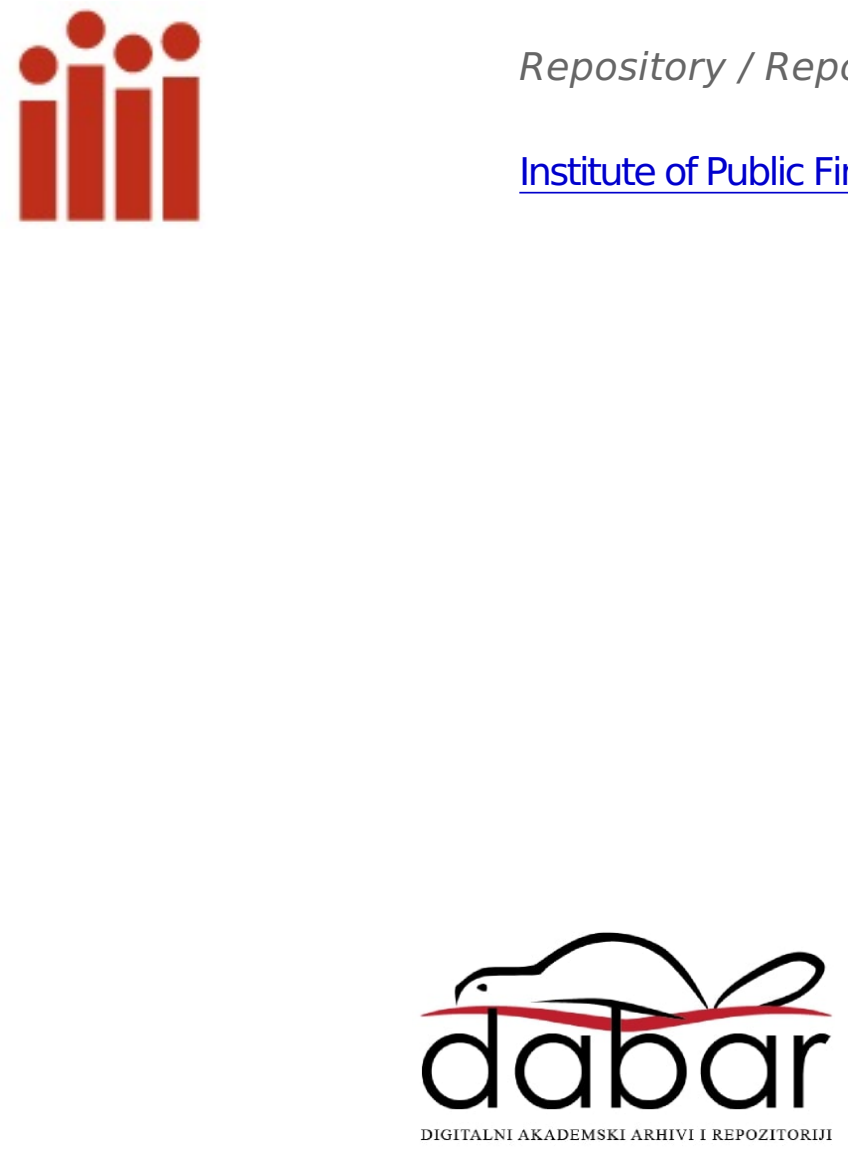


\section{DISTRIBUCIJA IMOVINE KUĆANSTAVA U HRVATSKOJ}

DotT. mag. Des MARINA KunOVAC*

\author{
IZVORNI ZNANSTVENI ČLANAK** \\ JEL: D1, D31, C35 \\ DOI: $10.3326 /$ OP.54
}

\section{ODABRANI PRIJEVODI}

\section{BR. 54}

\section{0. \\ ISSN: 1847-7445 \\ doi: 10.3326/op}

\section{citirati:}

Kunovac M., 2020. Distribution of household assets in Croatia Public Sector Economics, 44 (3), str. 265 - 297. https://doi.org/10.3326.pse.44.3.1

\section{SAŽETAK}

Ovaj rad temeljem podataka iz Ankete o financijama i potrošnji kućanstava (AFPK) analizira glavne komponente i distribuciju neto imovine kućanstava u Hrvatskoj, uzimajući u obzir različite sociodemografske karakteristike kućanstava. Glavni rezultati pokazuju da je realna imovina široko rasprostranjena među kućanstvima te 85\% kućanstava posjeduje glavnu stambenu jedinicu, dok su financijska imovina i obveze koncentrirane među imućnijim kućanstvima. Analiza glavnih determinanti koje određuju poziciju kućanstva u distribuciji imovine dodatno je istaknula važnost glavne stambene jedinice (GSJ). Kućanstva s naslijeđenom GSJ imaju manju vjerojatnost da se nalaze u najnižoj kvintilnoj skupini po vrijednosti neto imovine, dok kućanstva čija je GSJ locirana u Gradu Zagrebu ili Primorju imaju veću vjerojatnost da se nalaze u višim kvintilnim skupinama imovine. Utvrđena je i važnost razine dohotka kućanstva, obrazovanja, statusa na tržištu rada i starosti referentne osobe na vjerojatnost da se kućanstvo nalazi u određenoj kvintilnoj skupini neto imovine.

Ključne riječi: anketni podaci, Anketa o financijama i potrošnji kućanstava (AFPK), neto imovina kućanstava, nejednakost kućanstava, međugeneracijski transferi, Hrvatska

* Autorica zahvaljuje dvojici anonimnih recenzenata kao i Maji Bukovšak, Vedranu Šošiću, Krunoslavu Zauderu, Mati Rosanu, Ervinu Durakoviću, Lani Ivičić i Ivici Rubilu na korisnim komentarima i prijedlozima. Dio Stata koda za integraciju generaliziranih probit modela s utvrđenim redoslijedom opcija s višestruko imputiranim i ponderiranim podacima dobiven je zahvaljujući ljubaznosti Frederique Savignac iz AFPK mreže, koautorici u radu Arrondel i sur. (2014.). Navodi u tekstu isključivo su stavovi autorice te ni u kojem slučaju ne izražavaju stajalište ili mišljenje Hrvatske narodne banke.

** Primljeno: 21. listopada 2019.

Prihvaćeno: 24. veljače 2020.

Marina KUNOVAC

Hrvatska narodna banka, Trg hrvatskih velikana 3, 10000 Zagreb, Hrvatska e-mail: marina.kunovac@hnb.hr ORCiD: 0000-0002-3200-5928 


\section{UVOD}

Eventualne nejednakosti u distribuciji različitih vrsta imovine među kućanstvima trebale bi biti uvažene pri dizajniranju javnih politika, poput monetarne i makroprudencijalne politike, ali i ostalih javnih politika (porezne, demografske, socijalne ili regionalne politike). Tako na primjer monetarna politika može imati redistributivni utjecaj na kućanstva u ovisnosti o inicijalnoj raspodjeli dohotka, imovine i obveza među kućanstvima, kao i o njihovoj izloženosti kanalu kamatnih stopa (Auclert, 2017.; Tzamourani, 2019.). I makroprudencijalna politika koja doprinosi očuvanju stabilnosti financijskog sustava u isto vrijeme može imati utjecaj na raspodjelu imovine među kućanstvima (Carpantier i sur. 2017.). Stoga je iznimno važno provođenje monetarne politike i dizajniranje makroprudencijalnih mjera namijenjenih očuvanju financijske stabilnosti nadopuniti analizom nejednakosti u raspodjeli imovine među kućanstvima.

Prethodno je nejednakost među kućanstvima u Hrvatskoj analizirana korištenjem isključivo podataka o dohocima (npr. Nestić 2005.; Rubil 2013.; Rubil i sur. 2018.). Ovaj rad nadovezuje se na postojeću literaturu o nejednakosti u raspodjeli dohotka među kućanstvima, te donosi analizu distribucije imovine za kućanstva u Hrvatskoj. Analiza se temelji na podacima prikupljenim u sklopu Ankete o financijama i potrošnji kućanstava - AFPK (engl. Household Financial and Consumption Survey - HFCS), koju je Hrvatska narodna banka (HNB) sredinom 2017. godine po prvi puta provela na uzorku kućanstava u Hrvatskoj, a koja sadržava detaljne podatke o realnoj i financijskoj imovini kućanstava, njihovim obvezama, dohocima, potrošnji kao i različite sociodemografske karakteristike kućanstva. ${ }^{1}$

Ovaj rad donosi nove spoznaje o distribuciji različitih komponenti neto imovine među kućanstvima u Hrvatskoj, kao i glavne determinante koje određuju relativnu poziciju kućanstva u distribuciji neto imovine. Prije implementacije ankete, imovina kućanstava u Hrvatskoj mogla se analizirati isključivo iz agregatnih izvora podataka, poput financijskih računa koji sadržavaju podatke o ukupnoj financijskoj imovini i obvezama, no koji ne sadržavaju informacije o distribuciji imovine i obveza, te nejednakosti među kućanstvima. Uz to, nije postojao prikladan izvor podataka za analizu realne imovine kućanstava.

Osim detaljne analize distribucije imovine među kućanstvima, ovaj rad istražuje i koje su glavne determinante koje određuju poziciju kućanstva u distribuciji neto imovine, uz pomoć generaliziranog probit modela s utvrđenim redoslijedom alternativa (engl. generalized ordered probit model). Prema saznanjima autorice, analiza determinanti koje utječu na poziciju kućanstva u distribuciji neto imovine nije do sada provedena za kućanstva u Hrvatskoj, dok za zemlje europodručja postoji ekstenzivna literatura (npr. Du Caju 2013.; Sierminska i Medgyesi 2013.; Kontbay-Busun i Peichl 2015.; Leitner 2015.; Fessler i Schürz 2015.; Arrondel i sur. 2014.), bazirana na podacima HFCS-a iz prethodna dva vala ankete.

\footnotetext{
${ }^{1}$ Anketa o financijama i potrošnji kućanstava provedena je u koordinaciji s Europskom središnjom bankom. Europska središnja banka već je koordinirala prethodna dva vala AFPK ankete, prvi u razdoblju od 2008.-2010. i drugi tijekom 2013. S obzirom da je Hrvatska pristupila EU u srpnju 2013. HNB se priključila provođenju ankete u trećem valu.
} 
Rezultati analize pokazuju da postoji nejednakost u raspodjeli pojedinih vrsta neto imovine među kućanstvima u Hrvatskoj. Realna imovina relativno je široko rasprostranjena među kućanstvima i zamjetno više zastupljena nego u ostalim zemljama EU, s obzirom na to da 85\% kućanstava posjeduje glavnu stambenu jedinicu. ${ }^{2}$ Medijalna vrijednost glavne stambene jedinice kućanstava je 66 tisuća eura, te ona predstavlja najveći dio vrijednosti ukupne neto imovine kućanstava. S druge strane, zabilježena je izražena nejednakost u posjedovanju financijske imovine, s obzirom na to da samo neka kućanstva posjeduju značajne iznose financijske imovine, dok je medijalna vrijednost financijske imovine kućanstava u Hrvatskoj 500 eura. Rezultati deskriptivne analize pokazuju da distribucija ukupne neto imovine varira među kućanstvima, u ovisnosti o njihovim sociodemografskim karakteristikama, dohotku, vlasništvu nad nekretninom i geografskoj lokaciji unutar koje unutar koje kućanstvo prebiva.

Kada je riječ o determinantama koje određuju poziciju kućanstva u distribuciji neto imovine rezultati generaliziranog probit modela s utvrđenim redoslijedom alternativa pokazuju da postoji povezanost između pozicije kućanstva u distribuciji dohotka i imovine, no njezina statistička signifikantnost i intenzitet varira u ovisnosti o poziciji kućanstva unutar distribucije dohotka. Ovaj rezultat robustan je za različite specifikacije dohotka kućanstava. Način stjecanja glavne stambene jedinice važan je u objašnjavanju vjerojatnosti da kućanstvo pripada određenoj kvintilnoj skupini imovine, za niže razine imovine, dok postaje nesignifikantan za određivanje vjerojatnosti da se kućanstvo nalazi u imućnijim kvintilnim skupinama po vrijednosti neto imovine.

Analiza je pokazala i važnost geografske lokacije glavne stambene jedinice, pri čemu uz sve ostale faktore nepromijenjene, kućanstva s glavnom stambenom jedinicom u Gradu Zagrebu ili u Primorju imaju zamjetno veću vjerojatnost da se nalaze u višim kvintilnim skupinama neto imovine u usporedbi s kućanstvima čija je glavna stambena jedinica locirana u Istočnoj Hrvatskoj. Nadalje, obrazovanje, status na tržištu rada i godine starosti također imaju signifikantan utjecaj na poziciju kućanstva u distribuciji neto imovine, pri čemu kućanstva s obrazovanijim i starijim referentnim osobama, te kućanstva gdje je referentna osoba samozaposlena imaju veću vjerojatnost da se nalaze među imućnijim kućanstvima.

Rad je strukturiran na sljedeći način: osnovne informacije o tehničkoj provedbi ankete i dizajnu uzorka dane su u drugom poglavlju. Treće poglavlje donosi detaljne informacije o glavnim komponentama neto imovine: realnoj i financijskoj imovini i obvezama, njihovoj rasprostranjenosti među kućanstvima i vrijednosti. U četvrtom se poglavlju analizira nejednakost u raspodjeli neto imovine među kućanstvima, uzimajući u obzir različite socio demografske karakteristike kućanstva. U petom se poglavlju koristi ekonometrijski model da bi se utvrdilo koje su karakteristike kućanstva povezane s vjerojatnošću da se kućanstvo nalazi u određenoj kvintilnoj skupini po vrijednosti neto imovine. Šesto poglavlje daje pregled glavnih zaključaka provedene analize.

\footnotetext{
${ }^{2}$ Usporedba s podacima prikupljenim u EU tijekom drugog vala ankete 2013. pokazala je da je posjedovanje glavne stambene jedinice zamjetno rasprostranjenije u Hrvatskoj u usporedbi s EU gdje stambenu jedinicu posjeduje u prosjeku 62\% kućanstava, medijalne vrijednosti 165 tisuća eura (HFCN 2016.).
} 


\section{PROVEDBA ANKETE}

Anketu o financijama i potrošnji kućanstava u Hrvatskoj naručila je HNB, a provela ju je agencija za istraživanje tržišta Ipsos u suradnji s Državnim zavodom za statistiku (DZS). Anketni upitnik izrađen je u sklopu istraživačke mreže Europske središnje banke (ESB) te je harmoniziran među zemljama EU-a. Anketa je u Hrvatskoj provedena u razdoblju od ožujka do lipnja 2017., a odnosila se na 2016. godinu.

Stratifikacija privatnih kućanstava iz populacije u bruto uzorak provedena je u dvije etape. ${ }^{3} \mathrm{U}$ prvoj etapi stratificirani su segmenti prema nastanjenim stanovima u prostornim jedinicama Republike Hrvatske (koji pripadaju istoj općini (gradu) ili gradskoj četvrti za Zagreb, prema popisnim krugovima iz Popisa 2011.). Segmenti su podijeljeni u dvije skupine prema kvadraturi stambenog prostora (do $120 \mathrm{~m}^{2}$ i više od $120 \mathrm{~m}^{2}$ ). U drugoj etapi stratifikacije uzorka segmenti su podijeljeni prema geografskoj lokaciji na Primorje, Istočnu Hrvatsku i Središnju Hrvatsku te prema tipovima administrativnih jedinica (grad ili općina), dok zasebne stratume čine Grad Zagreb, te gradovi Split i Rijeka. Ovakvom je stratifikacijom dobiveno ukupno 16 različitih stratuma. Nakon određivanja stratuma, unutar svakog stratuma odabran je broj segmenata proporcionalan njihovoj veličini. Na ovaj način je osigurano da kućanstva imaju jednaku vjerojatnost izbora, neovisno o tome u kojem se stratumu nalaze. Sveukupno se u 16 stratuma nalazi 800 segmenata iz 552 naselja. Naposljetku je unutar svakog segmenta nasumično odabrano 5 nastanjenih stanova, što ukupno odgovara uzorku od 4000 nastanjenih stanova u kojima prema Popisu 2011. živi 4070 kućanstava koja su odabrana u bruto uzorak ove ankete.

Vermeulen (2014. i 2016.) pokazuje da ukoliko je izostanak odgovora ispitanika povezan s imovinskim statusom to može dovesti do podcjenjivanja ukupne imovine procijenjene anketom. Kao jednu od strategija za ublažavanje problema izostanka odgovora imućnijih kućanstava Vermulen (2016.) predlaže dodatnu zastupljenost bogatijih kućanstava u uzorku, pri čemu se kao kriterij za odabir kućanstva u uzorak predlaže neka mjera imovine kućanstva. Tijekom provedbe AFPK ankete za Hrvatsku, kao mjera imovine kućanstva koja služi kao kriterij za odabir kućanstva u uzorak odabrana je kvadratura stambenog prostora kućanstva.

Stoga su tijekom uzorkovanja dodatno zastupljena kućanstva koja imaju kvadraturu stambenog prostora veću od $120 \mathrm{~m}^{2}$, te takva kućanstva čine $25 \%$ bruto uzorka, dok je njihov udio u populaciji 10\%. U bruto uzorku su dodatno zastupljena i kućanstva koja se nalaze u Gradu Zagrebu, te u Splitu i Rijeci (35\% bruto uzorka naspram $25 \%$ populacije), jer ovi gradovi tradicionalno bilježe niske stope odaziva prema rezultatima prethodnih anketa. Na ovaj način pokušalo se umanjiti problem podzastupljenosti imućnijih kućanstava u uzorku. ${ }^{4}$

\footnotetext{
${ }^{3}$ Prema metodologiji AFPK ankete koju propisuje ESB, institucionalna kućanstva nisu obuhvaćena anketom.

4 Recentna istraživanja (npr. Blanchet i sur. 2018.) ukazuju da se najdetaljnija korekcija podzastupljenosti imućnih kućanstava u anketama o dohotku može ostvariti kombinacijom anketnih i poreznih podataka. Autori predlažu statističku proceduru koja kombinira mikro podatke o dohotku prikupljene anketom i porezne podatke o broju poreznih obveznika u pojedinom dohodovnom razredu, što rezultira novim prilagođenim setom podataka sa novim ponderima i opservacijama, u kojem su vrijednosti dohotka korigirane, dok se zadržava konzistencija ostalih podataka prikupljenih anketom.
} 
TABLICA 1.

Struktura kućanstava u bruto i realiziranom uzorku, te u ukupnoj populaciji

\begin{tabular}{|c|c|c|c|c|c|c|}
\hline \multirow[b]{2}{*}{ Stratum } & \multicolumn{2}{|c|}{ Bruto uzorak } & \multicolumn{2}{|c|}{ Realizirani uzorak } & \multicolumn{2}{|c|}{ Populacija } \\
\hline & $\begin{array}{l}\text { Broj slučajno } \\
\text { odabranih } \\
\text { stanova u } \\
\text { stratumu }\end{array}$ & $\%$ & $\begin{array}{l}\text { Broj kućanstava } \\
\text { koji su } \\
\text { odgovorili na } \\
\text { AFPK anketu }\end{array}$ & $\%$ & $\begin{array}{l}\text { Broj } \\
\text { nastanjenih } \\
\text { stanova u } \\
\text { populaciji }\end{array}$ & $\%$ \\
\hline $\begin{array}{l}\text { Središnja HR, grad, } \\
\text { kvadratura GSJ < } 120\end{array}$ & 220 & 6 & 74 & 5 & 124.958 & 8 \\
\hline $\begin{array}{l}\text { Središnja HR, općina, } \\
\text { kvadratura GSJ < } 120\end{array}$ & 150 & 4 & 59 & 4 & 96.573 & 6 \\
\hline $\begin{array}{l}\text { Grad Zagreb, } \\
\text { kvadratura GSJ }<120\end{array}$ & 830 & 21 & 133 & 10 & 279.420 & 19 \\
\hline $\begin{array}{l}\text { Istočna HR, grad, } \\
\text { kvadratura GSJ < } 120\end{array}$ & 485 & 12 & 229 & 17 & 230.580 & 15 \\
\hline $\begin{array}{l}\text { Istočna HR, općina, } \\
\text { kvadratura GSJ < } 120\end{array}$ & 225 & 6 & 128 & 9 & 140.397 & 9 \\
\hline $\begin{array}{l}\text { Primorje, grad, } \\
\text { kvadratura GSJ }<120\end{array}$ & 480 & 12 & 158 & 12 & 232.817 & 16 \\
\hline $\begin{array}{l}\text { Primorje, općina, } \\
\text { kvadratura GSJ < } 120\end{array}$ & 230 & 6 & 64 & 5 & 128.137 & 9 \\
\hline $\begin{array}{l}\text { Gradovi Split i Rijeka, } \\
\text { kvadratura GSJ < } 120\end{array}$ & 380 & 10 & 103 & 8 & 111.113 & 7 \\
\hline $\begin{array}{l}\text { Središnja HR, grad, } \\
\text { kvadratura GSJ > } 120\end{array}$ & 155 & 4 & 63 & 5 & 26.420 & 2 \\
\hline $\begin{array}{l}\text { Središnja HR, općina, } \\
\text { kvadratura GSJ > } 120\end{array}$ & 100 & 3 & 52 & 4 & 19.602 & 1 \\
\hline $\begin{array}{l}\text { Grad Zagreb, } \\
\text { kvadratura GSJ > } 120\end{array}$ & 195 & 5 & 60 & 4 & 20.557 & 1 \\
\hline $\begin{array}{l}\text { Istočna HR, grad, } \\
\text { kvadratura GSJ > } 120\end{array}$ & 225 & 6 & 125 & 9 & 33.039 & 2 \\
\hline $\begin{array}{l}\text { Istočna HR, općina, } \\
\text { kvadratura GSJ > } 120\end{array}$ & 95 & 2 & 50 & 4 & 18.635 & 1 \\
\hline $\begin{array}{l}\text { Primorje, grad, } \\
\text { kvadratura GSJ > } 120\end{array}$ & 115 & 3 & 28 & 3 & 17.641 & 1 \\
\hline $\begin{array}{l}\text { Primorje, općina, } \\
\text { kvadratura GSJ > } 120\end{array}$ & 85 & 2 & 21 & 2 & 14.064 & 1 \\
\hline $\begin{array}{l}\text { Gradovi Split i Rijeka, } \\
\text { kvadratura GSJ > } 120\end{array}$ & 30 & 1 & 10 & 1 & 2.605 & 0,2 \\
\hline Ukupno & 4000 & 100 & 1537 & 100 & 1.496 .558 & 100 \\
\hline
\end{tabular}

Napomena: Geografska lokacija Primorje uključuje: Primorsko-goransku, Ličko-senjsku, Zadarsku, Šibensko-kninsku, Splitskodalmatinsku, Istarsku i Dubrovačko-neretvansku županiju. Geografska lokacija Istočna HR uključuje: Sisačko-moslavačku, Karlovačku, Bjelovarsko-bilogorsku, Virovitičko-podravsku, Požeško-slavonsku, Brodsko-posavsku, Osječko-baranjsku i Vukovarskosrijemsku županiju. Geografska lokacija Središnja HR uključuje: Zagrebačku, Krapinsko-zagorsku, Varaždinsku, Koprivničkokriževačku i Međimursku županiju.

Izvor: AFPK, izračun autorice. 
Istraživanje je provedeno osobnim intervjuima uz podršku prijenosnog računala (engl. Computer Assisted Personal Interview - CAPI). Od kućanstava odabranih u bruto uzorak na anketu je odgovorilo ukupno 1357 kućanstva, što znači da je stopa odgovora iznosila 33\%. S obzirom na to da relativno visok broj izostavljenih odgovora (engl. unit non resposnse) i heterogenost stope odgovora u različitim dijelovima populacije (Tablica 1.) realizirani uzorak je ponderiran ${ }^{5}$, a izračun pondera uzima u obzir vjerojatnost izbora kućanstva u uzorak i heterogenost odgovora među različitim dijelovima populacije. Nadalje, svi ponderi su dodatno kalibrirani da odražavaju dobnu i spolnu distribuciju stanovništva prema Popisu iz 2011.

S obzirom na to da se unutar realiziranog uzorka kućanstava mogu nedostajati podaci za pojedina pitanja (engl. item non response), isti su nadomješteni stohastičkom višestrukom imputacijom. Prema preporukama ESB-a nedostajući podaci za pojedina pitanja unutar realiziranog uzorka imputirani su €MIR metodologijom, koja podrazumijeva da je izostanak odgovora na pojedina pitanja slučajan (engl. missing at random), te se nedostajući podaci zamjenjuju s nekoliko različitih vrijednosti koje su dobivene procjenama stohastičkog modela. ${ }^{6}$ Na ovaj se način dobije nekoliko različitih finalnih verzija ankete, koje se razlikuju samo prema imputiranim vrijednostima nedostajućih podataka. Gore opisane procese odabira uzorka, ponderiranja i imputacije je prema naputcima AFPK mreže ESB-a proveo DZS, te je HNB-u isporučeno 5 imputiranih verzija ankete, $\mathrm{s}$ pripadajućim ponderima. Detaljni podaci o izboru uzorka, provedbi ankete na terenu, sadržaju upitnika, te imputaciji i ponderiranju rezultata, mogu se pronaći u Jemrić i Vrbanc (u pripremi), a dodatni podaci o realiziranom uzorku prikazani su u Tablici 4.

Pri prikazu svih rezultata u ovom radu korištena je statistička procedura opisana u Boes (2006.) koja je dizajnirana za obradu višestruko imputiranih podataka u Stati. Također, u deskriptivnoj analizi su korišteni i procijenjeni ponderi, no oni nisu primijenjeni u procjeni ekonometrijskog modela. ${ }^{7}$

\section{GLAVNE KOMPONENTE IMOVINE I OBVEZA KUĆANSTAVA ${ }^{8}$}

U Tablici 2. prikazane su vrijednosti glavnih komponenti realne i financijske imovine i obveza kućanstava. Za svaku analiziranu vrstu imovine i obveza dostupni su podaci o udjelu kućanstava koja posjeduju određenu vrstu imovine/obveza u ukupnoj populaciji, te njihovim prosječnim i medijalnim vrijednostima. Tablica 2. prikazuje i udio svake pojedinačne komponente u ukupnoj vrijednosti imovine/obveza što odražava relativnu važnost različitih vrsta imovine i obveza za kućanstva. Prikazane vrijednosti svih komponenti imovine i obveza predstavljaju subjektivnu procjenu kućanstva, koja se ne mora nužno podudarati s tržišnim vrijednostima.

Rezultati prikazani u Tablici 2. pokazuju da 98\% kućanstava u Hrvatskoj posjeduje neku vrstu imovine (realne ili financijske), a njena medijalna vrijednost je 67 tisuća eura. Pri tome realna

\footnotetext{
${ }^{5} \mathrm{Na}$ ovaj način se uzela u obzir nejednaka vjerojatnost za sudjelovanje u uzorku među kućanstvima.

${ }^{6}$ Modeli za procjenu nedostajućih vrijednosti za pojedine varijable su unaprijed specificirani unutar AFPK mreže.

7 Sličan pristup primijenjen je i u Arrondel i sur. (2014.) i Georgokoponus (2019.). Ponderi se temelje na podacima o geografskoj rasprostranjenosti kućanstava, te dobi i spolu ispitanika, a kontroliranje za te varijable u modelu se obavlja njihovim direktnim uključivanjem u regresiju.

8 Odabrani dijelovi ovog poglavlja prikazani su u HNB (2019.a).
} 
imovina čini $97 \%$ vrijednosti ukupne imovine, a preostalih $3 \%$ vrijednosti ukupne imovine čini financijska imovina. Međutim, kod interpretacije ovih vrijednosti treba uzeti u obzir da usporedba s financijskim računima upućuje na podcijenjenost financijske imovine u anketi, budući da financijski računi pokazuju oko 7 puta veću vrijednost financijske imovine kućanstava. S druge strane, ostali podaci prikupljeni anketom za koje je moguća usporedba s drugim izvorima podataka (poput sociodemografskih karakteristika kućanstava, ukupne vrijednosti dohodaka i udjela vlasništva nad glavnom stambenom jedinicom) u skladu su s vrijednostima zabilježenim u alternativnim izvorima podataka (Jemrić i Vrbanc (u pripremi)).

Ukupna realna imovina kućanstava obuhvaća različite vrste nekretnina, vozila i ostale dragocjenosti (nakit, umjetnine, antikviteti i slično) koje kućanstvo posjeduje. Detaljna analiza komponenti realne imovine pokazuje da je njena vrijednost prvenstveno određena vrijednošću glavne stambene jedinice, koja čini $75 \%$ vrijednosti ukupne realne imovine kućanstava. Sveukupno, 85\% kućanstava posjeduje glavnu stambenu jedinicu, a njena je medijalna vrijednost 66 tisuća eura. Usporedba s podacima prikupljenim u EU tijekom drugog vala ankete 2013. pokazala je da je posjedovanje glavne stambene jedinice zamjetno rasprostranjenije u Hrvatskoj u usporedbi s EU gdje stambenu jedinicu posjeduje u prosjeku $62 \%$ kućanstava, a čija je medijalna vrijednost 165 tisuća eura. Ipak, i ostale zemlje koje su prošle kroz proces privatizacije stambenog fonda u društvenom vlasništvu 90-tih godina, poput Estonije, Slovenije i Slovačke imaju slično visok udio vlasništva nad glavnom stambenom jedinicom. ${ }^{9}$

Daljnja razdioba podataka o vlasničkom statusu nad glavnom stambenom jedinicom za Hrvatsku pokazuje da među 85\% kućanstava koja posjeduju glavnu stambenu jedinicu 77\% kućanstava je posjeduje u cijelosti, a preostalih $8 \%$ posjeduje neki njen dio. Nadalje, $6 \%$ kućanstava živi u stambenoj jedinici koju unajmljuje, a 9\% kućanstava slobodno koristi stambenu jedinicu, iako ona nije direktno u vlasništvu kućanstva. Načini stjecanja vlasništva nad glavnom stambenom jedinicom zamjetno variraju među kućanstvima, te ju je 36\% kućanstava sagradilo, 34\% naslijedilo ili dobilo na dar, $28 \%$ ju je kupilo, a preostalih $2 \%$ je steklo vlasništvo nad glavnom stambenom jedinicom kombinacijom prethodnih opcija.

Kada je riječ o ostalim komponentama realne imovine kućanstava, rezultati ankete pokazuju da 23\% kućanstava posjeduje dodatnu nekretninu, čija je medijalna vrijednost zamjetno niža u usporedbi s glavnom stambenom jedinicom i iznosi 20 tisuća eura. Nadalje, 69\% kućanstava posjeduje vozila, medijalne vrijednosti 4 tisuće eura po kućanstvu. Imovinu od samozapošljavanja posjeduje 5\% kućanstava, medijalnog iznosa 25 tisuća eura, dok prosječni iznos imovine od samozapošljavanja iznosi čak 209 tisuća eura, što upućuje da imovina od samozapošljavanja znatno pridonosi ukupnoj nejednakosti.

\footnotetext{
${ }^{9}$ HFCN (2016.)
} 
TABLICA 2.

Komponente imovine i obveza kućanstava

\begin{tabular}{|c|c|c|c|c|}
\hline \multirow[t]{2}{*}{ Komponente neto imovine } & \multirow{2}{*}{$\begin{array}{c}\begin{array}{l}\text { Udjel } \\
\text { kućanstva }\end{array} \\
\text { u \% }\end{array}$} & \multicolumn{2}{|r|}{ Prosjek } & \multirow{2}{*}{$\begin{array}{l}\text { Udjel u ukupnoj } \\
\text { vrijednosti } \\
\text { imovine/obveza } \\
\text { u \% }\end{array}$} \\
\hline & & u tisuća & Ima eura & \\
\hline (1) Realna imovina & 94 & 70 & 114 & 97 \\
\hline Glavna stambena jedinica & 85 & 66 & 94 & 73 \\
\hline Ostale nekretnine & 23 & 20 & 54 & 11 \\
\hline Vozila & 69 & 4 & 6 & 4 \\
\hline Ostale dragocjenosti & 4 & 2 & 6 & 0 \\
\hline Imovina & 5 & & & \\
\hline od samozapošljavanja* & & 25 & 209 & 9 \\
\hline (2) Financijska imovina & 82 & 0,5 & 5 & 3 \\
\hline Tekući računi & 80 & 0,2 & 9 & 1 \\
\hline Štedni računi & 14 & 5 & 13 & 2 \\
\hline $\begin{array}{l}\text { Dobrovoljna mirovina/ } \\
\text { životno osiguranje }\end{array}$ & 6 & 5 & 6 & 0 \\
\hline Uzajamni fondovi & 1,4 & 3 & 4 & 0 \\
\hline Novac kod kućanstava & 3 & 2 & 6 & 0 \\
\hline Dionice & 5 & 2 & 4 & 0 \\
\hline Obveznice & 0,4 & 0,1 & 69 & 0 \\
\hline $\begin{array}{l}\text { Ostale vrste } \\
\text { financijske imovine }\end{array}$ & 0,7 & 0 & 0,2 & 0 \\
\hline (3) Obveze & 41 & 2 & 10 & - \\
\hline Hipotekarni dug & 9 & 20 & 30 & 66 \\
\hline Za glavnu stambenu jedinicu & 9 & 20 & 30 & 63 \\
\hline Za ostale nekretnine & 0,4 & 16 & 26 & 3 \\
\hline Nehipotekarni dug & 36 & 2 & 4 & 34 \\
\hline $\begin{array}{l}\text { Dug po } \\
\text { kreditnim linijama/prekoračenjima }\end{array}$ & 27 & 1 & 1 & 9 \\
\hline Dug po kreditnim karticama & 6 & 0,4 & 0,8 & 1 \\
\hline Ostali nehipotekarni krediti & 13 & 5 & 8 & 24 \\
\hline$(1+2)$ Bruto imovina & 98 & 67 & 111 & - \\
\hline$((1+2)-3)$ Neto imovina & 100 & 61 & 107 & - \\
\hline
\end{tabular}

Napomena: *Imovina od samozapošljavanja definirana je kao bilo koja komponenta realne imovine (nekretnine, vozila ili dragocjenosti) koju kućanstvo posjeduje a koja se koristi pri obavljanju djelatnosti samozapošljavanja. Bruto imovina dobivena je kao zbroj realne i financijske imovine. Neto imovina jednaka je iznosu bruto imovine umanjenom za obveze kućanstva. S obzirom na to da je anketa harmonizirana među zemljama EU-a sve vrijednosti u anketi izražene su u eurima. Medijan i prosjek su izračunati za ona kućanstva koja posjeduju određenu vrstu imovine.

Izvor: AFPK, izračun autorice.

Kompozicija financijske imovine kućanstava je iznimno homogena, što je u skladu sa zaključcima prethodnih valova AFPK ankete gdje je potvrđen izostanak diversifikacije financijske imovine u zemljama koje su siromašnije od prosjeka europodručja, poput Estonije, Slovačke, Slovenije, Portugala, Malte i Grčke. ${ }^{10}$ Prema rezultatima ankete za Hrvatsku, medijalna vrijednost financijske imovine iznosi 500 eura po kućanstvu, a najznačajniji dio financijske imovine odnosi se na depozite koje ima 81\% kućanstava i čija je medijalna vrijednost 300 eura. Pri tome prevladavaju depoziti na tekućim računima (80\%) dok su depoziti na štednim računima rjeđi (14\%). Nakon depozita, najznačajnije komponente financijske imovine prema rasprostranjenosti među

\footnotetext{
${ }^{10}$ Merikull i Room (2016.), str. 4.
} 
kućanstvima su udjeli u dobrovoljnim mirovinskim fondovima i životnom osiguranju (6\%) i dionice (5\%), dok su obveznice, uzajamni fondovi, novac kod kućanstava i ostale vrste financijske imovine vrlo rijetko rasprostranjene među kućanstvima u Hrvatskoj. Ipak, ove rezultate treba razmatrati s oprezom, s obzirom na to da agregirane vrijednosti financijske imovine dobivene AFPK anketom ukazuju na oko 7 puta manju vrijednost financijske imovine kućanstava u usporedbi s financijskim računima.

Nadalje, anketa je prikupila i detaljne podatke o obvezama kućanstava u Hrvatskoj. ${ }^{11}$ 41\% kućanstava ima neku vrstu obveza, pri čemu u ukupnoj vrijednosti obveza kućanstava dominira hipotekarni dug koji čini 66\% ukupne vrijednosti obveza kućanstava a nehipotekarni dug čini $34 \%$ ukupne vrijednosti obveza kućanstava. Unatoč visokoj ukupnoj vrijednosti, hipotekarni dug nije široko rasprostranjen među kućanstvima te samo 9\% kućanstava ima takvu vrstu duga, medijalne vrijednosti 20 tisuća eura. Niski udio hipotekarnog duga i istovremeno široko rasprostranjeno vlasništvo nad glavnom stambenom jedinicom mogu se povezati s procesom tranzicije kroz koji je Hrvatsko gospodarstvo prošlo 90-tih godina kada je većina (danas starijeg stanovništva) došla u posjed glavne stambene jedinice privatizacijom stambenog fonda $\mathrm{u}$ društvenom vlasništvu. ${ }^{12}$ Naposljetku, 36\% kućanstava ima nehipotekarni dug (u prvom redu dug po kreditnim linijama/prekoračenjima (27\%) i ostale nehipotekarne kredite (13\%)), medijalne vrijednosti 2 tisuće eura.

Kada se uzme u obzir ukupna suma svih vrsta imovine umanjena za ukupne obveze kućanstava, dobije se ukupna neto imovina kućanstava. Prema rezultatima ankete, medijalna vrijednost neto imovine kućanstava iznosi 61 tisuću eura, a prosječna 107 tisuća eura. Na Grafikonu 1.a prikazana je distribucija neto imovine po percentilima, koja pokazuje da najsiromašnijih $5 \%$ kućanstava gotovo nema imovine. Iznad 5. percentila vrijednost neto imovine postupno raste sve do 75 . percentila. Rast vrijednosti neto imovine ubrzava nakon 75. percentila, što je pogotovo izraženo na samom repu distribucije nakon 90. percentila. Grafikon 1.b. prikazuje topologiju najznačajnijih vrsta imovine među kućanstvima, te pokazuje da neka kućanstva istovremeno posjeduju nekoliko vrsta imovine, poput glavne stambene jedinice, dodatne stambene jedinice i oročenih depozita, no takvih je kućanstava relativno malo (6\%).

\footnotetext{
11 Detalji o obvezama kućanstava prikupljeni AFPK anketom opisani su u HNB (2019.) i Rosan i Zauder (2019.). Prethodno su Herceg i Šošić (2011.) i Herceg i Nestić (2014.) analizirali distribuciju duga među kućanstvima u Hrvatskoj. Navedene analize temeljile su se međutim na Anketi o potrošnji kućanstava DZS-a, koja sadržava mikro podatke o dugu te glavne sociodemografske karakteristike kućanstva, dok podaci o imovini (realnoj ili financijskoj) nisu bili dostupni.

12 Privatizacija stambenog fonda u društvenom vlasništvu odvila se sukladno Zakonu o prodaji stanova nad kojima postoji stanarsko pravo (NN, 27/1991.).
} 


\section{GRAFIKON 1.A}

Distribucija neto imovine,

u tisućama eura

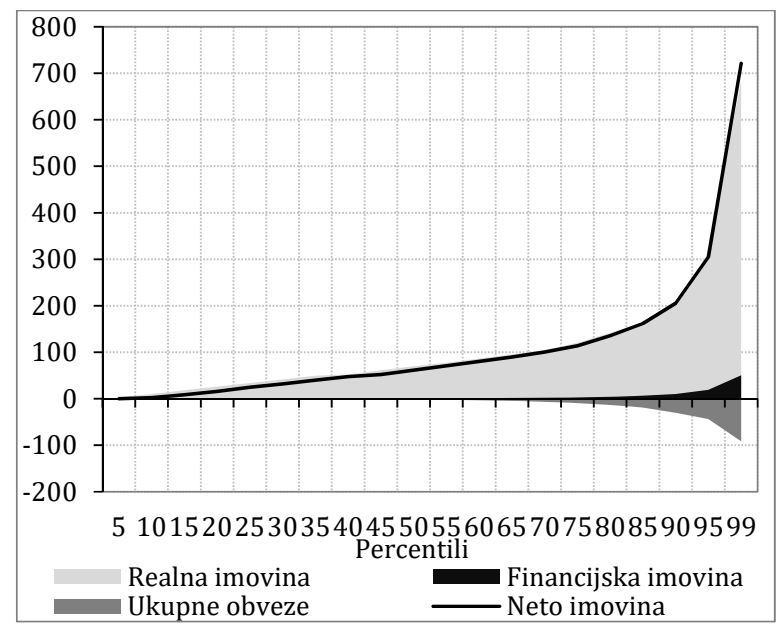

GRAFIKON 1.B

Topologija imovine kućanstava

(najvažnije komponente), udjel kućanstava

Glavna stambena

jedinica (85\%)
Dodatna stambena jedinica $(23 \%)$

Sve tri vrste imovine (6\%)

Oročeni

depoziti (14\%)

Izvor: AFPK, izračun autorice.

\section{NEJEDNAKOST U RASPODJELI NETO IMOVINE KUĆANSTAVA}

Nejednakost u raspodjeli različitih vrsta imovine među kućanstvima prikazana je uz pomoć Lorenzove krivulje i Ginijevog koeficijenta. Nadalje, s obzirom na to da se prethodna literatura o nejednakosti kućanstava u Hrvatskoj temelji na nejednakostima koje proizlaze iz dohotka kućanstava prikazana je i Lorenzova krivulja dohotka prema podacima prikupljenim AFPK anketom. Lorenzova krivulja je grafički prikaz nejednakosti, kojim je na x-osi prikazan kumulativni udio kućanstava a na y-osi kumulativni udio imovine koju kućanstva posjeduju. U slučaju ravnomjerne raspodjele imovine, Loreznova krivulja bila bi jednaka dijagonali kvadrata (tzv. linija savršene jednakosti). Što je nejednakost distribucije imovine manja, Lorenzova krivulja je bliža dijagonali, a što je nejednakost veća Lorenzova krivulja udaljenija je od dijagonale. Ginijev koeficijent je omjer površine omeđene Lorenzovom krivuljom i dijagonalom kvadrata i ukupne površine trokuta koji se nalazi ispod dijagonale kvadrata.

Ginijev koeficijent za ukupnu neto imovinu kućanstava iznosi 0,61, što upućuje da je nejednakost u raspodjeli neto imovine u Hrvatskoj manja u usporedbi s prosjekom europodručja, s obzirom na to da Ginijev koeficijent za neto imovinu kućanstava $\mathrm{u}$ europodručju prema podacima prikupljenim tijekom drugog vala AFPK ankete 2013. iznosi 0,69 (HFCN (2016.)).

Grafikon 2. pokazuje da je nejednakost u raspodjeli financijske imovine (Ginijev koeficijent 0,88) puno izraženija od nejednakosti u raspodjeli realne imovine (Ginijev koeficijent 0,59). Ovakva opažanja tipična su za zemlje s visokim udjelom vlasništva nad glavnom stambenom jedinicom (85\% u Hrvatskoj prema rezultatima ankete), koje doprinosi širokoj rasprostranjenosti realne imovine među kućanstvima. ${ }^{13}$ Izražena nejednakost u raspodjeli financijske imovine u skladu je s

\footnotetext{
${ }^{13}$ Zanimljiv je primjer Austrije, u kojoj je nejednakost u raspodjeli financijske imovine manja od nejednakosti u raspodjeli realne imovine, s obzirom na nizak udio vlasništva nad glavnom stambenom jedinicom koji iznosi $45 \%$. Za više detalja vidi Fessler i sur. (2019.).
} 
rezultatima prikazanim u HNB (2016.), gdje se prikazuje Lorenzova krivulja štednje fizičkih osoba u RH za 2014.

Ginijev koeficijent pojedinih potkomponenti realne i financijske imovine prikazan je u Tablici 5.

\section{GRAFIKON 2.}

Lorenzova krivulja za realnu, financijsku i neto imovinu i dohodak

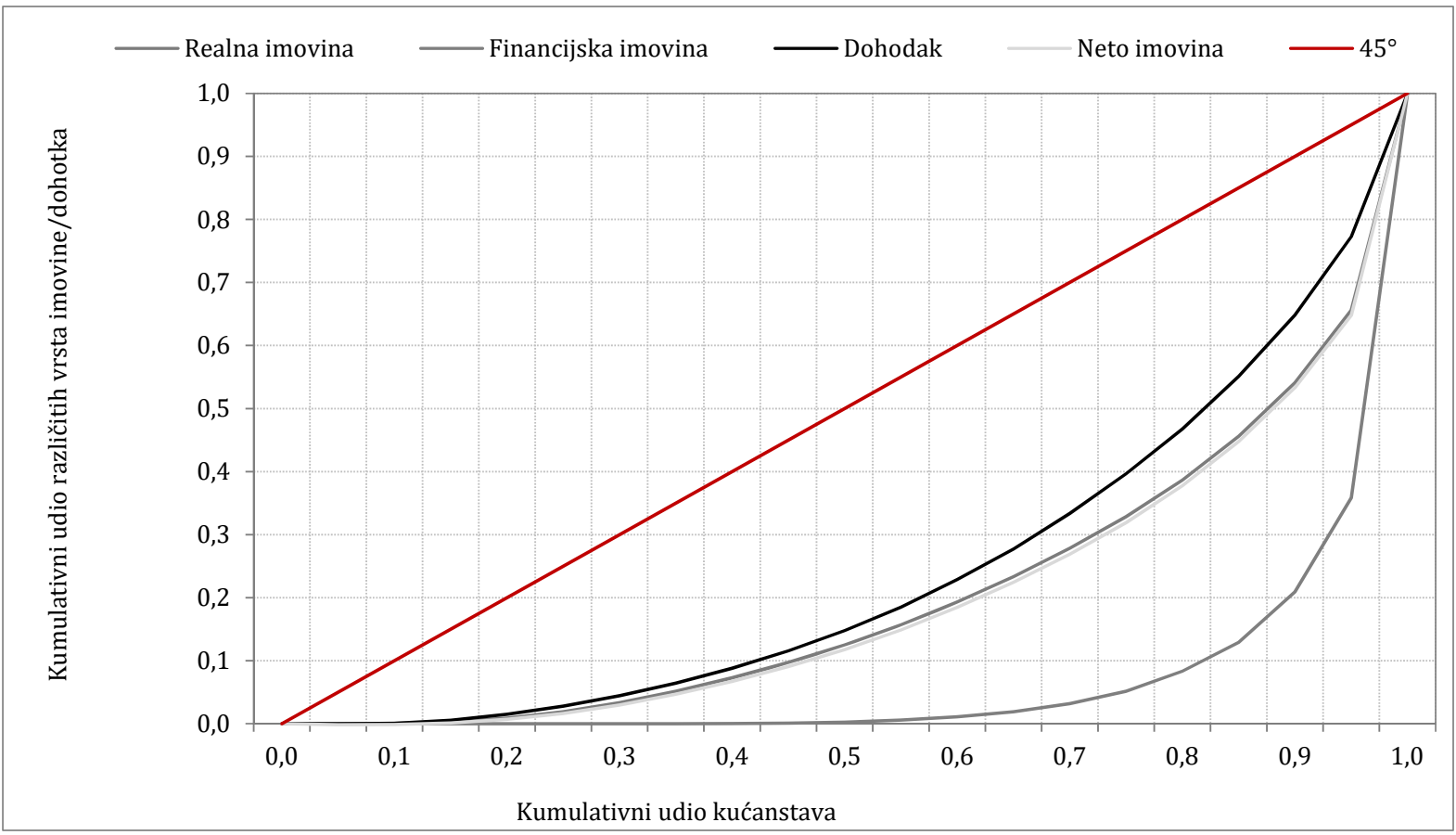

Izvor: AFPK, izračun autorice.

Kada je riječ o dohotku, usporedba distribucije imovine i bruto dohotka među kućanstvima pokazuje da je nejednakost u distribuciji bruto dohotka niža od nejednakosti realne ili financijske imovine (Ginijev koeficijent dohotka je 0,51). ${ }^{14}$ Iako se u analizama nejednakosti i blagostanja obično koristi koncept neto dohotka, AFPK anketa prikuplja isključivo podatke o bruto iznosima dohotka - dakle, prije odbitaka za poreze i socijalno osiguranje, stoga se u nastavku analizira nejednakost bruto dohotka. Pri tome AFPK anketa vjerojatno precjenjuje nejednakost u raspodjeli bruto dohotka. Naime, u anketi provedenoj u Hrvatskoj velik je broj kućanstava koja su izjavila da nemaju nikakvu vrstu dohotka i čiji je godišnji bruto dohodak nula (7\%), a neka od njih istodobno imaju velike vrijednosti imovine. Budući da ukupni godišnji bruto dohodak uključuje dohotke od rada, rente, prihode od financijske imovine, mirovine, socijalne transfere ili bilo kakve druge izvore dohotka, taj rezultat upućuje na to da se radi o podacima čija je stvarna vrijednost namjerno izostavljena iz odgovara na upitnik. Stoga je procijenjen i Ginijev koeficijent bruto dohotka za ona kućanstva čiji je godišnji bruto dohodak veći od 1300 eura (iznos je odabran s obzirom na to da

\footnotetext{
${ }^{14}$ Podaci iz Ankete o dohotku stanovništva DZS-a za 2016. također upućuju na manju nejednakost u raspodjeli dohotka za kućanstva u Hrvatskoj, no u slučaje Ankete o dohotku stanovništva Ginijev koeficijent dohotka je zamjetno niži i iznosi 0,3 (DZS, (2017.)). Rezultati nisu u potpunosti usporedivi s obzirom na to da se Ginijev koeficijent iz Ankete o dohotku stanovništva odnosi na neto dohodak, dok se svi prikupljeni podaci o dohotku u AFPK anketi odnose na bruto iznose - dakle, iznose prije odbitaka za poreze i socijalno osiguranje.
} 
kućanstvo koje se sastoji od jedne osobe prima minimalno 800 kuna mjesečno, koliki je iznos Zajamčene minimalne naknade (NN, 152/2014.)), te on iznosi 0,44.

Dostupnost detaljnih anketnih podataka omogućuje daljnju evaluaciju međupovezanosti između nejednakosti u raspodjeli neto imovine i različitih karakteristika kućanstva. Analiza glavnih sociodemografskih karakteristika referentne osobe $\mathrm{u}$ kućanstvu, ${ }^{15}$ poput spola, razine obrazovanja, godina starosti ili statusa na tržištu rada, prikazana na Grafikonu 3., pokazuje da postoji korelacija između razine obrazovanja i vrijednosti neto imovine, te se među kućanstvima čija je referentna osoba visokoobrazovana nalazi najveći udio osoba (30\%) čija je vrijednost neto imovine u najvišoj, petoj kvintilnoj skupini. Udio osoba koje se nalaze u najvišoj imovinskoj kvintilnoj kategoriji raste s dobi referentne osobe, da bi se nakon umirovljenja blago smanjio. Kada je riječ o statusu na tržištu rada, izdvajaju se samozaposlene osobe koje su najzastupljenije u najvišoj imovinskoj kvintilnoj kategoriji (više od 50\% samozaposlenih osoba pripada petoj imovinskoj kvintilnoj skupini). S druge strane, kod kućanstava u kojima je referentna osoba neaktivna, prevladavaju relativno siromašna kućanstva te se više od 50\% kućanstava nalazi u prvoj kvintilnoj skupini po vrijednosti neto imovine.

\section{GRAFIKON 3.}

Sociodemografske karakteristike kućanstava i kvintilne skupine neto imovine, u \%

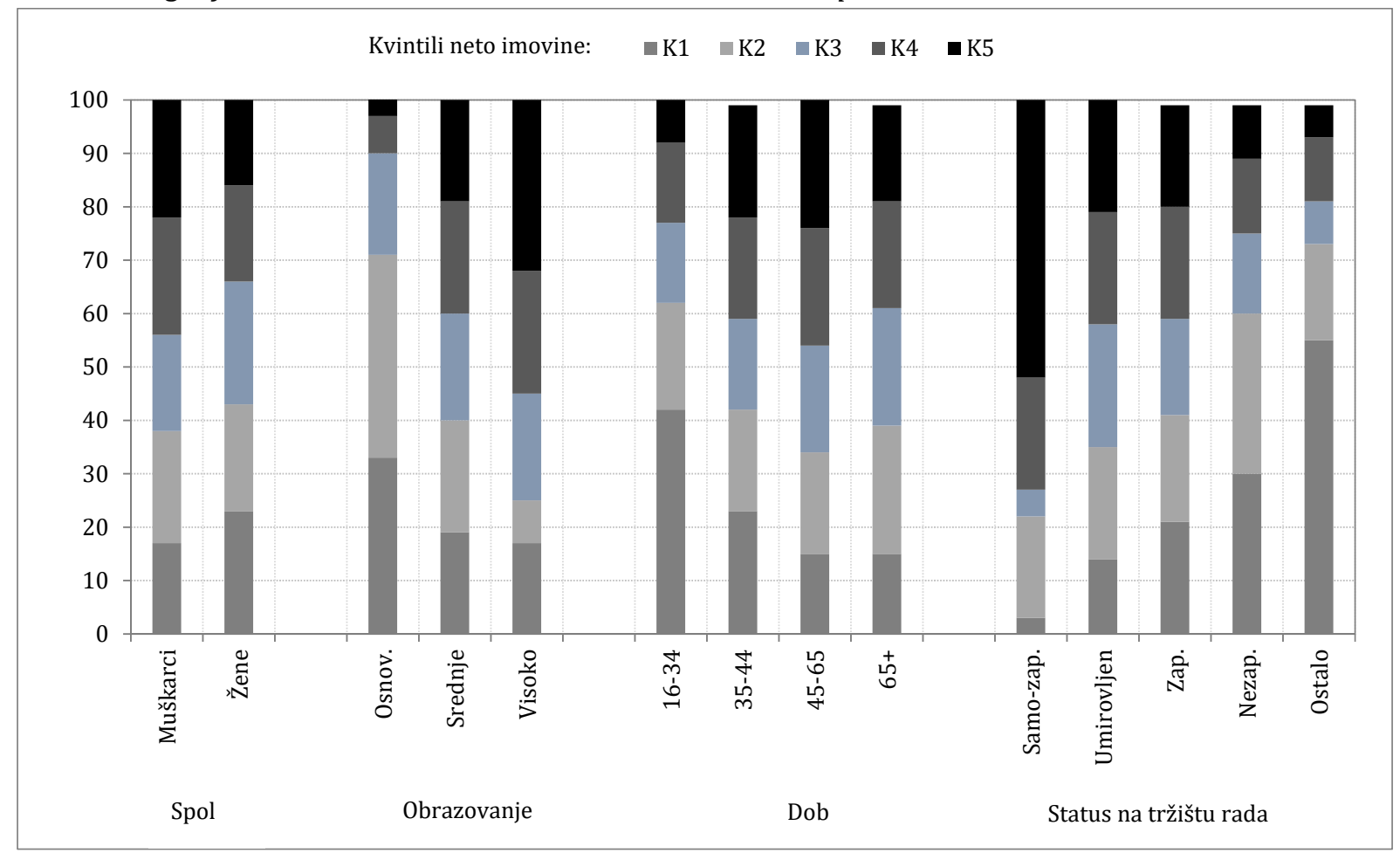

Izvor: AFPK, izračun autorice.

Obrazovanje, status na tržištu rada i godine starosti povezani su i s razinom dohotka kućanstva, a dohodak određuje i vrijednost neto imovine koja se može aproksimirati štednjom od tekućeg dohotka akumuliranom kroz vrijeme i uvećanom za međugeneracijske transfere i darove

\footnotetext{
${ }^{15}$ Referentna osoba definirana je od strane članova kućanstava kao osoba koja je najinformiranija o financijama kućanstva.
} 
(detaljnu raspravu vidi u Du Caju (2016.)). Međupovezanost između razine dohotka i nejednakosti u raspodjeli neto imovine među kućanstvima prikazana je na Grafikonu 4.a. Kućanstva koja najviše zarađuju (nalaze se u najvišoj dohodovnoj kvintilnoj skupini) ujedno su i među najimućnijima (nalaze se u najvišoj kvintilnoj skupini neto imovine), i to u $40 \%$ slučajeva. S druge strane, kućanstva koja se nalaze u najnižoj dohodovnoj kvintilnoj skupini najčešće posjeduju neto imovinu male vrijednosti, ali nije zanemariv i udjel onih koji istovremeno imaju visoku vrijednost neto imovine (17\% kućanstava nalazi se u najnižoj dohodovnoj i najvišoj imovinskoj kvintilnoj kategoriji). Iako se u literaturi navodi nekoliko mogućih objašnjenja zašto se neka kućanstva nalaze u najnižim kvintilnim skupinama po vrijednosti dohotka, a u najvišima po vrijednosti imovine, poput visokog udjela umirovljenika u prvoj kvintilnoj skupini dohotka koji trenutačno imaju niska primanja, ali su prethodno akumulirali značajna imovinska sredstva ili eventualnog utjecaja međugeneracijskih transfera koji nisu vezani uz visinu dohotka, detaljna dekompozicija podataka pokazala je da ta objašnjenja ne vrijede za kućanstva u Hrvatskoj. Naime, kako je već prethodno istaknuto, u anketi provedenoj u Hrvatskoj velik je broj kućanstava koja su izjavila da nemaju nikakvu vrstu dohotka (7\%), a kako po definiciji ankete godišnji bruto dohodak uključuje dohotke od rada, rente, prihode od financijske imovine, mirovine, socijalne transfere ili bilo kakve druge izvore dohotka, ovakav rezultat upućuje da se radi o podacima čija je stvarna vrijednost namjerno izostavljena iz odgovara prilikom intervjuiranja. ${ }^{16}$

\section{GRAFIKON 4.A}

Zajednička distribucija dohotka i neto imovine - ukupno

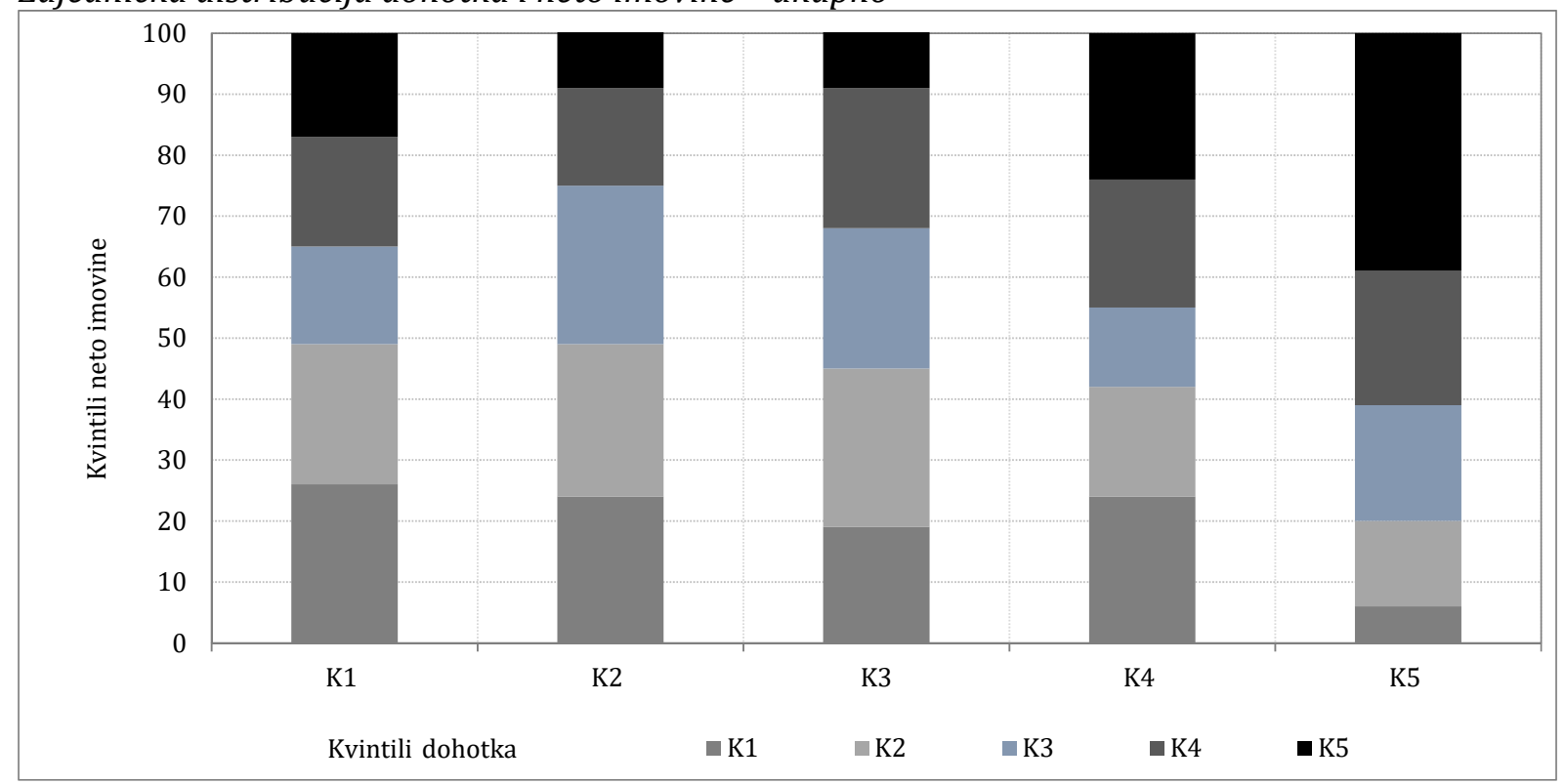

Izvor: AFPK, izračun autorice.

Stoga se na Grafikonu 4.b prikazuje distribucija imovine i dohotka za ona kućanstva čiji je godišnji bruto dohodak veći od 1300 eura (iznos Zajamčene minimalne naknade za kućanstvo). Ipak, i kada se iz uzorka ispuste kućanstva koja imaju bruto godišnji dohodak manji od 1300 eura, i dalje postoje

\footnotetext{
${ }^{16}$ Komponente dohotka koje su uključene u definiciju bruto godišnjeg dohotka, te komponente svih ostalih varijabli čije se vrijednosti prikupljaju anketom dostupne su u HFCN (2019.a).
} 
kućanstva koja imaju vrlo niske dohotke i istodobno posjeduju visoke vrijednosti neto imovine. Stoga ispitujemo i ostale faktore koji mogu utjecati na nejednakost u raspodjeli neto imovine.

\section{GRAFIKON 4.B}

Zajednička distribucija dohotka i neto imovine - godišnji bruto dohodak kućanstva iznad 1300 eura

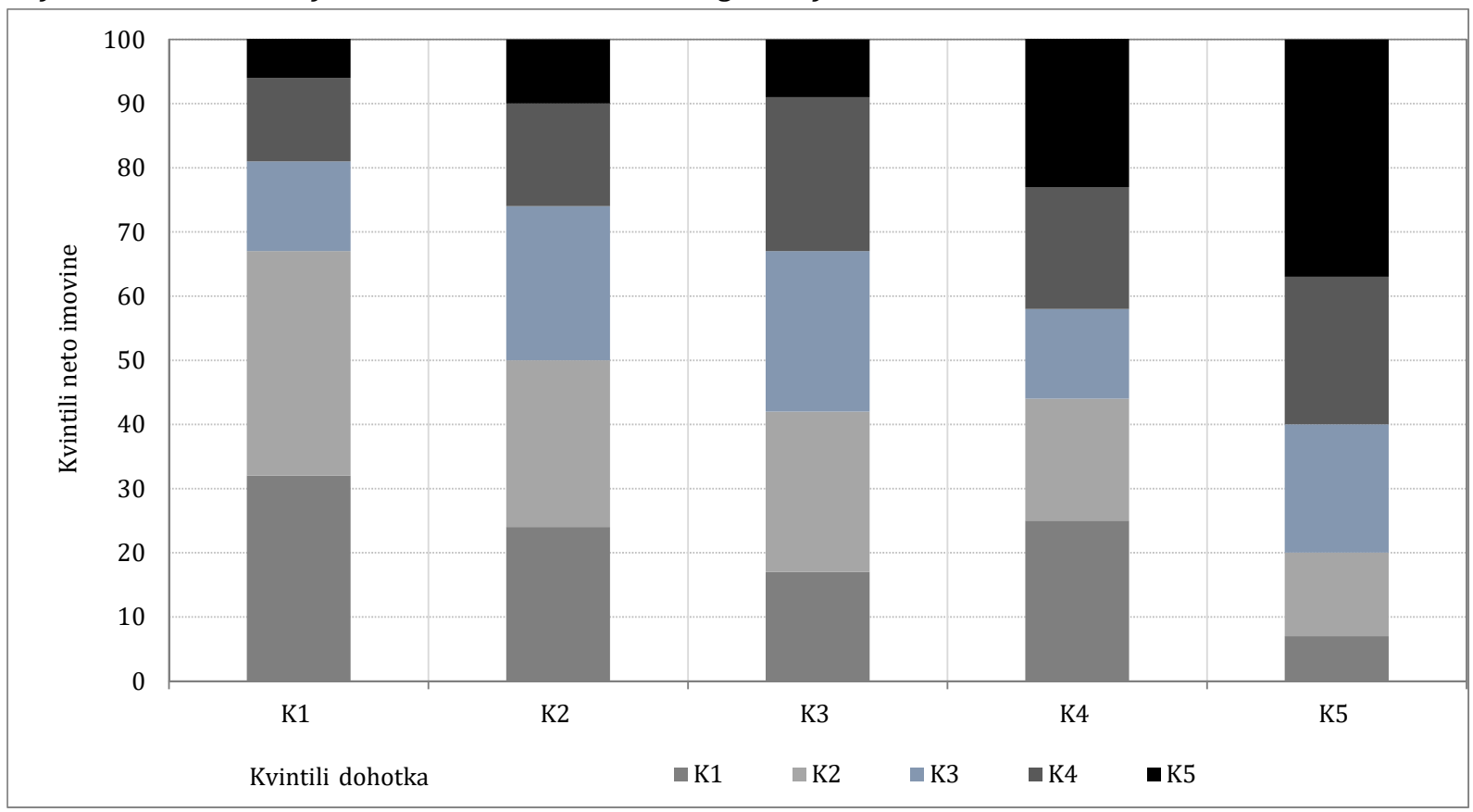

Izvor: AFPK, izračun autorice.

Recentna istraživanja (Piketty (2013.), Zucman i Piketty (2015.)) ukazuju da neovisno o dohotku, odlučujući utjecaj na nejednakost $u$ raspodjeli neto imovine mogu imati međugeneracijski transferi, pri čemu dominantnu ulogu ima nasljeđivanje stambene jedinice. Međupovezanost između vlasničkog statusa nad glavnom stambenom jedinicom, i načina stjecanja glavne stambene jedinice, kao najznačajnije komponente neto imovine, s ukupnom vrijednosti neto imovine kućanstava prikazana je na Grafikonima 5.a i 5.b. Grafikon 5.a pokazuje da se kućanstva koja unajmljuju ili slobodno koriste glavnu stambenu jedinicu nalaze među najsiromašnijima. $S$ druge strane udio kućanstava koja posjeduju glavnu stambenu jedinicu raste s 5\% među kućanstvima s najnižom neto imovinom na 95\% među kućanstvima s najvišom neto imovinom. Kada je riječ o načinu stjecanja glavne stambene jedinice, Grafikon 5.b pokazuje da među kućanstvima u najnižim decilima neto imovine prevladavaju kućanstva koja nemaju glavnu stambenu jedinicu, što je i očekivano s obzirom na to da je glavna stambena jedinica najvrjednija determinanta imovine. U 1 . decilu imovine udio kućanstava koja su naslijedila stambenu jedinicu iznosi tek 3\%, dok je u ostalim decilima prosjek kućanstava koja su naslijedila stambenu jedinicu podjednak, i iznosi u prosjeku oko $30 \%$. 


\section{GRAFIKON 5.A}

Vlasnički status glavne stambene jedinice i decili neto imovine, u \%

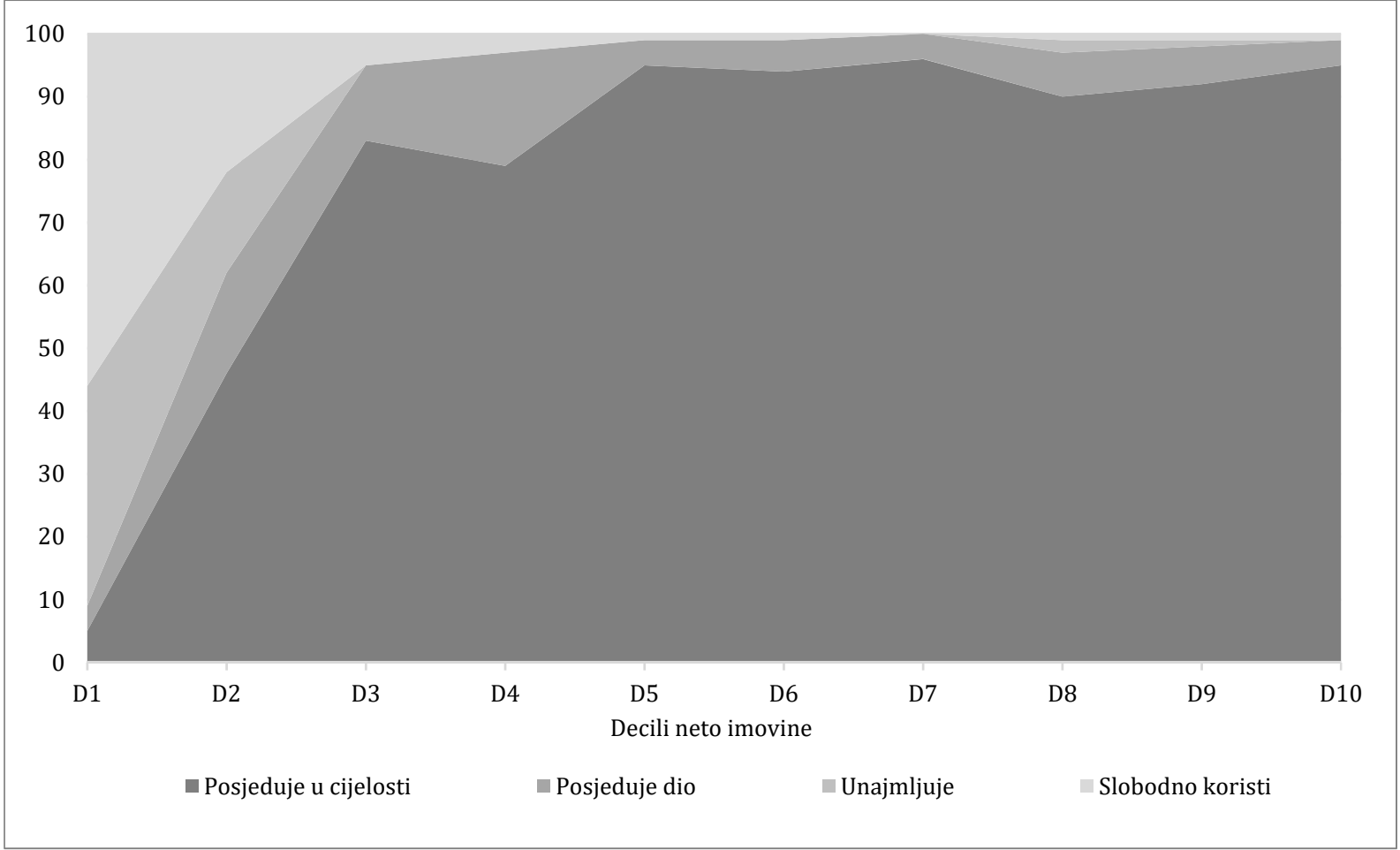

Izvor: AFPK, izračun autorice

\section{GRAFIKON 5.B}

Način stjecanja glavne stambene jedinice i decili neto imovine, $u$ \%

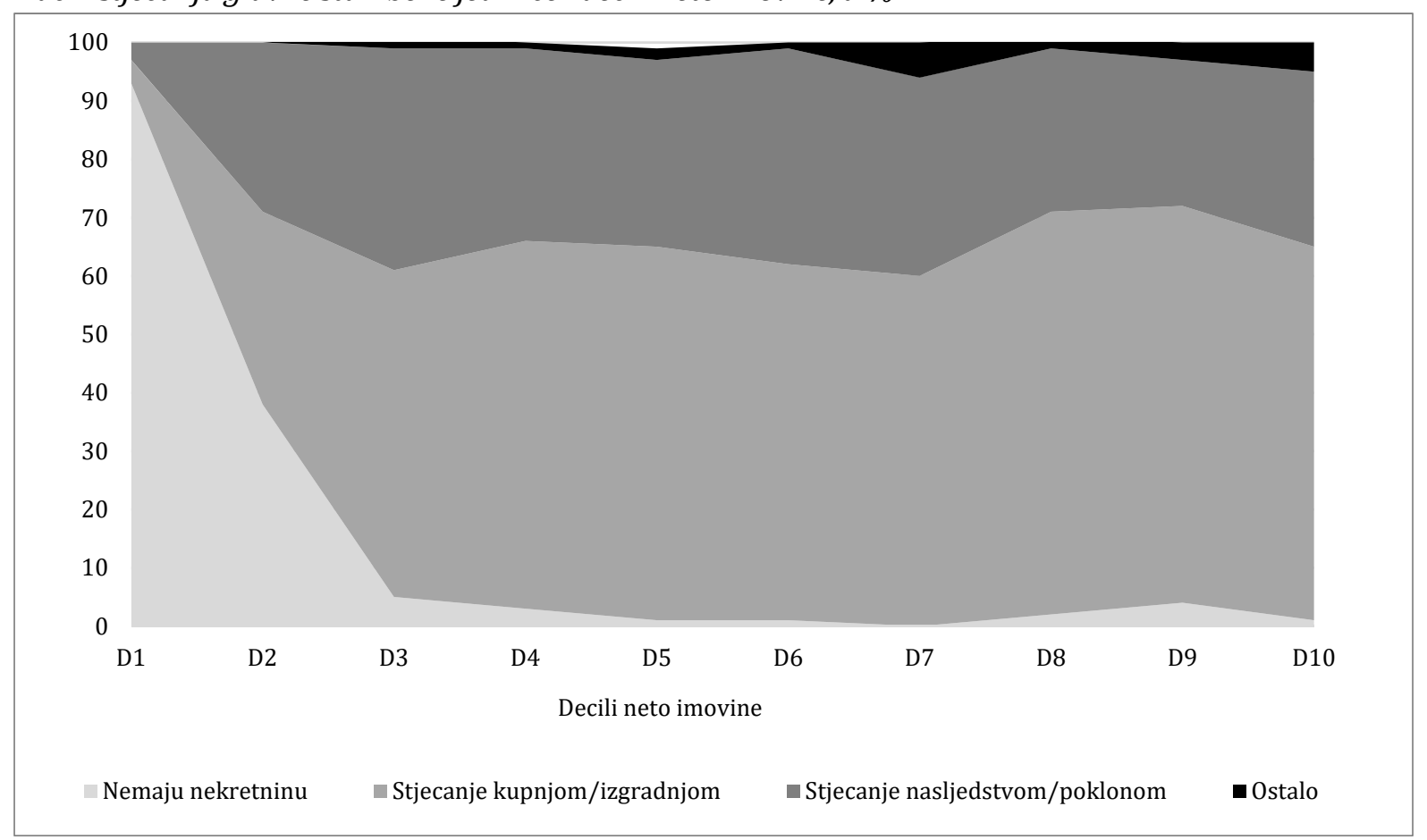

Izvor: AFPK, izračun autorice 
S obzirom na važnost vrijednosti glavne stambene jedinice u ukupnoj vrijednosti neto imovine kućanstva, uz vlasnički status i način stjecanja glavne stambene jedinice i geografska lokacija stambene jedinice mogla bi imati značajan utjecaj na vrijednost ukupne neto imovine kućanstva. Hrvatsko tržište nekretnina karakterizirano je snažnom regionalnom heterogenosti i zamjetnim razlikama u cijenama nekretnina s obzirom na regiju u kojoj se nekretnina nalazi (za više informacija vidi Tkalec i sur., 2018. i HNB (2019.)) Regionalna nejednakost karakterizira i ostala gospodarska kretanja,17 stoga u nastavku analiziramo vrijednost neto imovine kućanstava s obzirom na geografsku lokaciju kućanstva.

\section{GRAFIKON 6.A}

Regionalna heterogenost kućanstava s obzirom na vrijednost neto imovine

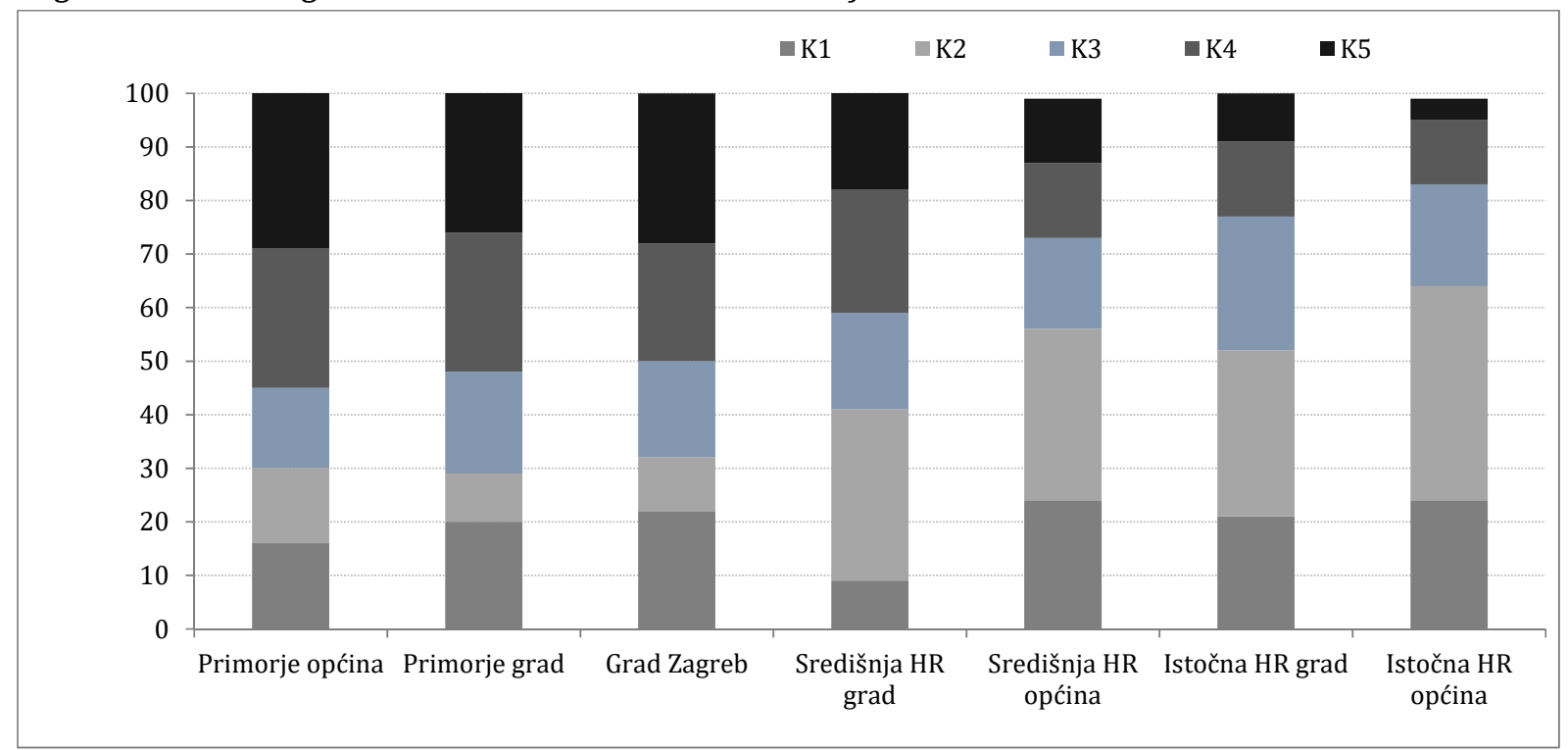

Napomena: Geografska lokacija Primorje uključuje: Primorsko-goransku, Ličko-senjsku, Zadarsku, Šibensko-kninsku, Splitsko-dalmatinsku, Istarsku i Dubrovačko- neretvansku županiju. Geografska lokacija Istočna HR uključuje: Sisačkomoslavačku, Karlovačku, Bjelovarsko-bilogorsku, Virovitičko-podravsku, Požeško-slavonsku, Brodsko-posavsku, Osječkobaranjsku i Vukovarsko-srijemsku županiju. Geografska lokacija Središnja HR uključuje: Zagrebačku, Krapinsko-zagorsku, Varaždinsku, Koprivničko-križevačku i Međimursku županiju.

Izvor: AFPK, izračun autorice.

Rezultati prikazani na Grafikonu 6.a pokazuju da se u geografskim lokacijama Primorja te u Gradu Zagrebu više od 50\% kućanstava može svrstati u 40\% najimućnijih, dok je u Istočnoj Hrvatskoj taj udio manji od 20\%, pri čemu se kao najsiromašnije izdvajaju općinska naselja u Istočnoj Hrvatskoj gdje više od 60\% stanovništva čine kućanstva koja su na razini Hrvatske klasificirana među 40\% kućanstava s najnižom vrijednosti neto imovine. Daljnja analiza nejednakosti među različitim geografskim lokacijama unutar Hrvatske prikazana je na Grafikonu 5.b, gdje područja koja se nalaze ispod pravca nagiba 45 stupnjeva u svakom promatranom percentilu imovine imaju niže vrijednosti neto imovine nego što iznosi vrijednost na uzorku cijele Hrvatske. Tako npr. kućanstvo koje zauzima 50. percentil po vrijednosti neto imovine u općinama u Istočnoj Hrvatskoj je istodobno na razini Hrvatske u 30. percentilu po vrijednosti neto imovine. Dakle, prosječno kućanstvo u općini Istočne Hrvatske osjetno je siromašnije od hrvatskog prosjeka. S druge strane, kućanstvo koje zauzima 50. percentil po vrijednosti neto imovine unutar geografskog područja

\footnotetext{
${ }^{17}$ Za detalje vidi Christiaensen i sur. (2019.).
} 
koje se sastoji od općina u Primorju istodobno zauzima 65. percentil po vrijednosti neto imovine na razini Hrvatske, što upućuje da je prosječno kućanstvo u općini u Primorju znatno boljeg imovinskog statusa od prosjeka Hrvatske. Ovi rezultati upućuju na izrazitu regionalnu heterogenost u vrijednosti neto imovine među kućanstvima.

\section{GRAFIKON 6.B}

Usporedba percentila neto imovine za kućanstvo u regiji i na razini Hrvatske

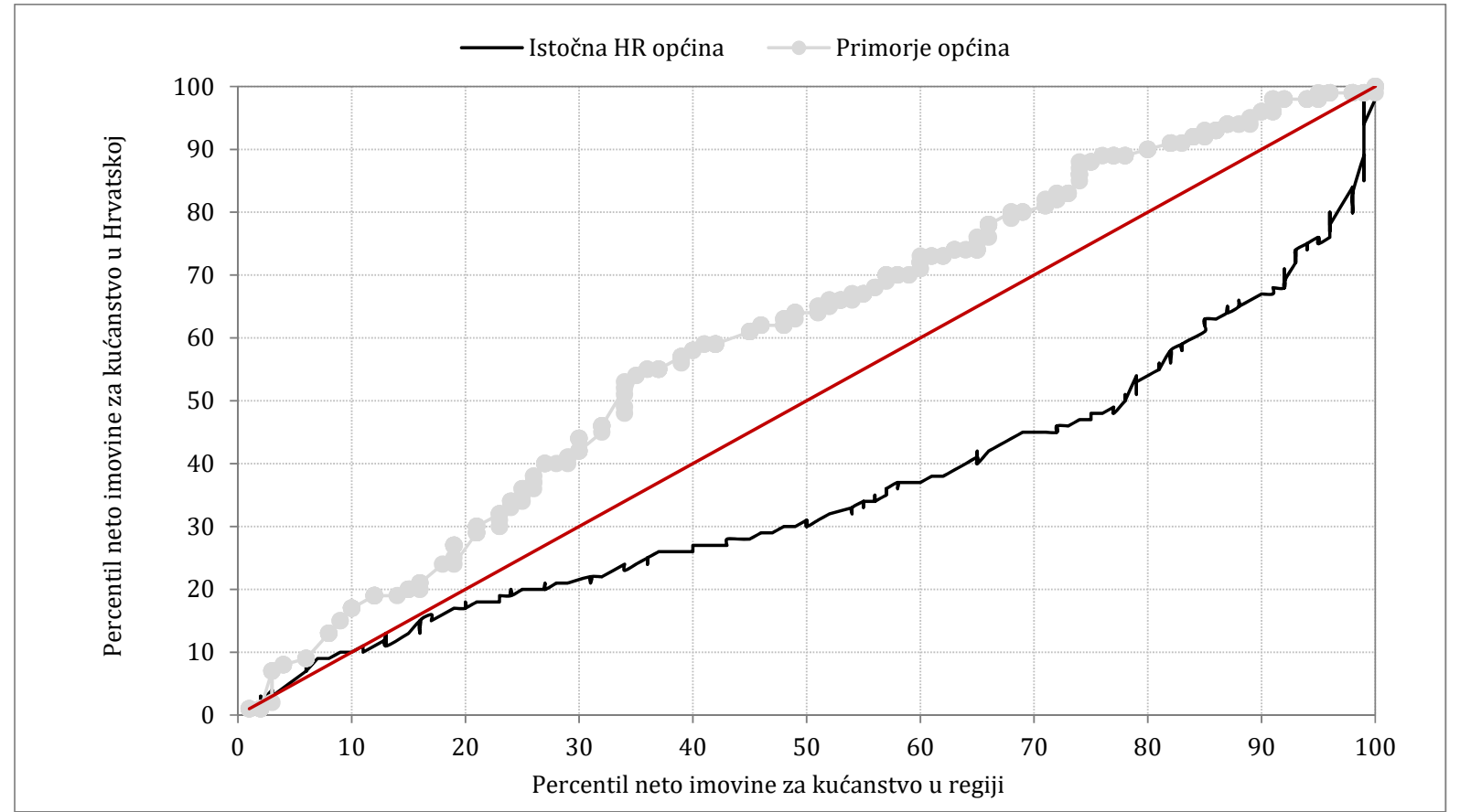

Napomena: Geografska lokacija Primorje uključuje: Primorsko-goransku, Ličko-senjsku, Zadarsku, Šibensko-kninsku, Splitsko-dalmatinsku, Istarsku i Dubrovačko- neretvansku županiju. Geografska lokacija Istočna HR uključuje: Sisačkomoslavačku, Karlovačku, Bjelovarsko-bilogorsku, Virovitičko-podravsku, Požeško-slavonsku, Brodsko-posavsku, Osječkobaranjsku i Vukovarsko-srijemsku županiju. Geografska lokacija Središnja HR uključuje: Zagrebačku, Krapinsko-zagorsku, Varaždinsku, Koprivničko-križevačku i Međimursku županiju.

Izvor: AFPK, izračun autorice.

Deskriptivne statistike korištene u ovom poglavlju pokazale su da vrijednost ukupne neto imovine zamjetno varira među kućanstvima, u ovisnosti o sociodemografskim karakteristikama i dohotku kućanstva, vlasništvu nad nekretninom i geografskoj lokaciji unutar koje kućanstvo prebiva. Ipak, deskriptivna analiza ne može pružiti detaljnije informacije o relativnoj važnosti različitih karakteristika kućanstva i njihovom utjecaju na distribuciju neto imovine među kućanstvima. Stoga se u sljedećem poglavlju koristi ekonometrijski model da bi se detaljno ispitao utjecaj različitih karakteristika kućanstva na nejednakost u raspodjeli neto imovine među kućanstvima. 


\section{ANALIZA GLAVNIH DETERMINANTI NEJEDNAKOSTI U RASPODJELI NETO IMOVINE}

U ovom poglavlju nastojimo ustvrditi osnovne determinante koje određuju nejednakost $\mathrm{u}$ raspodjeli neto imovine među kućanstvima. ${ }^{18}$ Sukladno deskriptivnoj analizi provedenoj u prethodnom poglavlju, zavisna varijabla kojom mjerimo nejednakost u raspodjeli neto imovine definirana je kao kvintilna skupina neto imovine kojoj kućanstvo pripada, te može poprimiti vrijednosti od 1 do 5 .

Eksplanatorne varijable podijeljene su u nekoliko glavnih kategorija:

Utjecaj relativne pozicije kućanstva u distribuciji dohotka na nejednakost u raspodjeli neto imovine uzima se u obzir korištenjem seta od pet indikatorskih varijabli koje poprimaju vrijednost 1 ako se kućanstvo nalazi u određenoj kvintilnoj skupini dohotka. Arrondel i sur. (2014.) pokazuju na uzorku zemalja koje su sudjelovale u drugom valu AFPK ankete da ne postoji jedinstvena poveznica između distribucije dohotka i imovine. Tako u nekim zemljama rast dohotka implicira i rast neto imovine za kućanstva, dok se u drugima poveznica između distribucije dohotka i imovine mijenja u ovisnosti o relativnoj poziciji kućanstva u distribuciji imovine.

S obzirom na važnost vrijednosti glavne stambene jedinice za ukupnu vrijednost neto imovine, diskutirane u prethodnom poglavlju, u analizu uključujemo i detaljne informacije o glavnoj stambenoj jedinici. Među ostalima, Piketty (2013.), Zucman i Piketty (2015.) smatraju da je nasljedstvo ključ za određivanje vrijednosti neto imovine kućanstva. Važnost uloge nasljedstva u određivanju vrijednosti neto imovine potvrđena je i na AFPK podacima prikupljenima tijekom prethodna dva vala ankete (HFCN (2013.) i HFCN (2016.)). Stoga u analizu uključujemo indikatorsku varijablu koja je jednaka 1 ako je kućanstvo izjavilo da je primilo u nasljedstvo glavnu stambenu jedinicu ili ju je dobilo na dar. Nadalje, s obzirom na heterogenost u vrijednosti glavne stambene jedinice među različitim geografskim lokacijama u Hrvatskoj konstruiramo set od četiri indikatorske varijable koje označavaju geografsku lokaciju glavne stambene jedinice i kućanstva (Primorje, Središnja Hrvatska, Istočna Hrvatska i Grad Zagreb). Mathä i sur. (2014.) koriste Oaxaca - Blinder dekompoziciju i pokazuju da razlike u cijenama nekretnina među zemljama europodručja imaju najveći doprinos pri objašnjavanju razlika u vrijednosti neto imovine kućanstava među zemljama.

Sociodemografske karakteristike kućanstva, temelje se na podacima o referentnoj osobi, koja je definirana od strane kućanstva kao osoba koja je najinformiranija o financijama kućanstva. U analizu je uključen set indikatorskih varijabli za dob referentne osobe (od 16 do 34 godina, od 35 do 45 godina, od 45 do 64 godine i iznad 65 godina). Hammer (2015.) analizira bilancu kućanstava u ovisnosti o dobi referentne osobe i pokazuje da imovina kućanstava raste s dobi referentne osobe, da bi se nakon umirovljenja blago smanjila. ${ }^{19} \mathrm{U}$ analizi je uzet je u obzir i spol referentne osobe, te je konstruirana indikatorska varijabla koja poprima vrijednost 1 ako je referentna osoba

\footnotetext{
${ }^{18}$ Odabir zavisnih varijabli i metodološki pristup sličan je kao u radovima Arrondel i sur. (2014.), Martinez i Uribe (2018.) i Georgokoponus (2019.).

${ }^{19}$ Ovo je u skladu s pretpostavkama teorije životnog ciklusa (eng. life-cycle hypothesis) prema Modigliani i Brumberg (1954.).
} 
muškog spola. Prethodna istraživanja (Sierminska i sur. (2017.)) pokazala su da kućanstva s muškom referentnom osobom mogu imati veću vrijednost neto imovine. Utjecaj obrazovanja referentne osobe ispitan je kroz tri indikatorske varijable koje označavaju osobe s osnovnim obrazovanjem ili bez obrazovanja, osobe sa srednjoškolskim obrazovanjem ili osobe s visokim obrazovanjem. Utjecaj statusa na tržištu rada referentne osobe na nejednakost u raspodjeli neto imovine mjeri se setom indikatorskih varijabli, koje razlikuju između samozaposlenih, zaposlenih, umirovljenih, te referentnih osoba koje su nezaposlene ili neaktivne. Lise (2011.) pokazuje da je nejednakost imovine određena statusom na tržištu rada, pri čemu se nezaposlene osobe i neaktivne osobe koje su izvan tržišta rada nalaze u zamjetno nepovoljnijoj poziciji.

Među sociodemografske karakteristike kućanstva uključujemo i indikatorske varijable koje opisuju strukturu kućanstva, poput ukupnog broja osoba koje čine kućanstvo i broja maloljetnih osoba u kućanstvu, s obzirom na to da očekujemo da je broj osoba koje žive u kućanstvu pozitivno, a broj maloljetne djece koja žive u kućanstvu negativno koreliran s visinom neto imovine. Fessler i sur. (2014.) pokazuju da je uključivanje kontrolnih varijabli o strukturi kućanstva relevantno za adekvatnu analizu neto imovine.

U analizu su uključene i neke dodatne karakteristike kućanstva, poput indikatorske varijable koja mjeri sklonost riziku kućanstva (te poprima vrijednost 1 ako je kućanstvo izjavilo da je spremno preuzeti značajne ili iznad prosječne financijske rizike pri odabiru vrsta štednje i investicija za kućanstvo), te indikatorske varijable koja je jednaka 1 ako kućanstvo prima neku vrstu socijalne pomoći. Fessler i Schürz (2015.) i Jappelli (1995.), pokazuju da je socijalna pomoć zapravo supstitut za akumulaciju imovine kućanstava, te da kućanstva koja primaju neku vrstu socijalne pomoći imaju značajno nižu neto imovinu u odnosu na ostala kućanstva.

Naposljetku, uloga duga u akumulaciji neto imovine ispitana je kroz dvije indikatorske varijable, za kućanstva koja posjeduju hipotekarni dug na glavnu stambenu jedinicu, i za kućanstva koja posjeduju potrošački dug. ${ }^{20}$

Osim opisanih varijabli, u Tablici 6. prikazani su rezultati analize robusnosti s alternativnim odabirom varijabli. S obzirom na to da je u uzorku detektiran relativno visok udjel kućanstava čiji ukupni godišnji dohodak ne prelazi 1300 eura (Poglavlje 3.) prikazane su procjene modela u kojem su kućanstva s dohodcima nižim od 1300 eura izostavljena iz uzorka, te su na novom uzorku procijenjene granične vrijednosti za svrstavanje svakog kućanstva u pripadajuće kvintilne skupine dohotka i neto imovine. Nadalje, dodatna analiza robusnosti provedena je korištenjem alternativne specifikacije dohotka kućanstva, koji je normaliziran za broj članova kućanstva prema OECD-ovoj skali korekcije (OECD (2011.)). Rezultati analize robusnosti su u skladu s glavnim rezultatima modela. U nastavku je objašnjena konstrukcija modela koji se koristi za procjenu utjecaja navedenog seta eksplanatornih varijabli na poziciju kućanstva u distribuciji neto imovine.

\footnotetext{
${ }^{20}$ Za diskusiju o utjecaju duga i različitih vrsta socijalne pomoći na nejednakost u raspodjeli imovine vidi Maestri i sur. (2014.).
} 


\subsection{METODOLOGIJA - GENERALIZIRANI PROBIT MODEL S UTVRĐENIM REDOSLIJEDOM ALTERNATIVA}

U procjeni ekonometrijskog modela koristimo generalizirani probit model s utvrđenim redoslijedom alternativa. Model je baziran na latentnoj zavisnoj varijabli $I_{i}^{*}$ koja je definirana kao:

$$
I_{i}^{*}=X_{i} \beta_{j}+\varepsilon_{i}
$$

gdje $i=1, \ldots, n$ indeksira kućanstva u uzorku, a $j \in\{1,2, \ldots, J\}$ indeksira kategorije probit modela.

Opažena varijabla $I_{i}$ može poprimiti vrijednosti definirane unutar skupa $\{1,2, \ldots$,$\} gdje je J=5$. Opažena varijabla definirana je na sljedeći način:

$$
\begin{aligned}
& I_{i}=1 \quad \text { ako je } I_{i}^{*} \leq K_{1} \\
& I_{i}=j \quad \text { ako je } I_{i}=j \quad \text { za } j=\{2, \ldots, J-1\} \\
& I_{i}=J \quad \text { ako je } I_{i}^{*} \geq K_{J-1}
\end{aligned}
$$

Gdje su $K_{j}$ procijenjene granične vrijednosti koje svrstavaju svako kućanstvo u pripadajuću kvintilnu skupinu neto imovine.

S obzirom na navedeno, vjerojatnost da se kućanstvo i nalazi u nekoj od $J$ kategorija koji odražavaju kvintilne skupine neto imovine dana je kao:

$$
\begin{aligned}
& \operatorname{Pr}\left(I_{i}=1\right)=F\left(X_{i} \beta_{1}\right) \\
& \operatorname{Pr}\left(I_{i}=j\right)=F\left(X_{i} \beta_{j}\right)-F\left(X_{i} \beta_{j-1}\right) \\
& \operatorname{Pr}\left(I_{i}=J\right)=1-F\left(X_{i} \beta_{J-1}\right)
\end{aligned} \quad \text { za } j=\{2, \ldots, J-1\}
$$

gdje je $F$ normalna kumulativna funkcija distribucije.

Generalizirani probit model s utvrđenim redoslijedom alternativa je odabran naspram standardnog probit modela s utvrđenim redoslijedom alternativa kao preferirana specifikacija modela s obzirom na to da dopušta heterogen utjecaj nezavisnih varijabli na zavisnu u ovisnosti o različitim kategorijama zavisne varijable (Williams (2006.), Green i Hensher (2010).). Stoga u generaliziranom modelu procijenjeni parametri $\beta_{j}$ variraju između $j$ kategorija zavisne varijable (kvintilnih skupina vrijednosti neto imovine kućanstva). Ako bismo zahtijevali da su procijenjeni koeficijenti $\beta_{j}$ jednaki za svaku od $j$ vrijednosti kategorije zavisne varijable, dobili bismo standardni probit model s utvrđenim redoslijedom alternativa. Standardni probit model s utvrđenim redoslijedom alternativa pretpostavljao bi linearan utjecaj svih nezavisnih varijabli na zavisnu varijablu. Tako bi npr. utjecaj dohotka bio jednak za određivanje vjerojatnosti da se kućanstvo nalazi u drugoj i u petoj kvintilnoj skupini prema vrijednosti neto imovine. S obzirom na to da Waldov test homogenosti procijenjenih koeficijenata (engl. parallel line assumption model) odbija pretpostavku homogenosti za procijenjene parametre, to potvrđuje prikladnost 
korištenja generaliziranog naspram standardnog probit modela s utvrđenim redoslijedom alternativa u analizi (rezultati testa prikazani u Tablicama 6., 7. i 8.). Nadalje, te tablice. sadrže i prikaz rezultata procjene metode najmanjih kvadrata, gdje je zavisna varijabla vrijednost neto imovine (log). No upotreba linearne regresije također pretpostavlja linearan utjecaj svih nezavisnih varijabli na zavisnu varijablu, dok je prethodno provedena univarijatna analiza pokazala da se kompozicija relevantnih karakteristika kućanstva zamjetno mijenja ovisno o samoj poziciji kućanstva u distribuciji neto imovine. Stoga je generalizirani probit model s utvrđenim redoslijedom alternativa odabran kao primarni metodološki pristup budući da omogućava nelinearan utjecaj nezavisnih varijabli u ovisnosti o različitim kategorijama zavisne varijable.

\subsection{GLAVNI REZULTATI}

U nastavku su prikazani glavni rezultati procjene generaliziranog probit modela s utvrđenim redoslijedom alternativa definiranog kao u jednadžbi (3). S obzirom na to da se regresijski koeficijenti ne mogu tumačiti kao marginalni efekti unutar probit modela u Tablicama 6., 7. i 8. prikazani su marginalni efekti, koji prikazuju utjecaj jedinične promjene eksplanatorne varijable na vjerojatnost da se pojedino kućanstvo nalazi u određenoj kvintilnoj skupini vrijednosti neto imovine. S obzirom na to da marginalni učinak može biti različit za različite vrijednosti eksplanatornih varijabli, navodi se marginalni učinak vrednovan po srednjoj vrijednosti eksplanatornih varijabli.

Glavni zaključci su sljedeći:

Empirijska analiza potvrđuje postojanje poveznice između pozicije kućanstva u distribuciji dohotka i imovine. Procijenjeni marginalni efekti za dohodak u većini slučajeva imaju očekivani predznak. Kućanstva s niskim dohocima imaju veću vjerojatnost da se nalaze u nižim i manju vjerojatnost da se nalaze u višim kvintilnim skupinama po vrijednosti neto imovine. Tako npr. kućanstvo koje se nalazi u prvoj dohodovnoj kvintilnoj skupini ima 14\% veću vjerojatnost da se nalazi u i prvoj kvintilnoj skupini po vrijednosti neto imovine, i $20 \%$ manju vjerojatnost da se nalazi u petoj (najvišoj) kvintilnoj kategoriji po vrijednosti neto imovine, u odnosu na kućanstvo koje se nalazi u petoj kvintilnoj kategoriji po vrijednosti dohotka. Neovisno o postojanju određene veze između dohotka i vrijednosti neto imovine statistička signifikantnost i intenzitet linka variraju, u ovisnosti o poziciji kućanstva unutar distribucije imovine, što upućuje da je nejednakost $\mathrm{u}$ raspodjeli imovine samo djelomično objašnjena razinom dohotka među kućanstvima, dok relevantan utjecaj na poziciju kućanstva u distribuciji neto imovine imaju i neki drugi faktori osim dohotka. ${ }^{21}$

\footnotetext{
${ }^{21}$ Ovakav rezultat potvrđen je i u drugim istraživanjima (npr. Arrondel i sur. (2014.), Leitner (2015.)).
} 
TABLICA 3.

Vjerojatnost da se kućanstvo nalazi u određenoj kvintilnoj skupini neto imovine*

\begin{tabular}{|c|c|c|c|c|c|c|}
\hline & & \multicolumn{5}{|c|}{ Kvintili neto imovine } \\
\hline & & 1 & 2 & 3 & 4 & 5 \\
\hline \multirow{4}{*}{$\begin{array}{l}\text { Dohodak } \\
\text { po kvintilima }\end{array}$} & 1 & $0,14^{* * *}$ & $0,14^{* * *}$ & $-0,04$ & $-0,05$ & $-0,20^{* * *}$ \\
\hline & 2 & $0,16^{* * *}$ & $0,13^{* * *}$ & 0,05 & $-0,06$ & $-0,28^{* * *}$ \\
\hline & 3 & $0,10 * * *$ & $0,11^{* * *}$ & 0,01 & 0,00 & $-0,22^{* * *}$ \\
\hline & 4 & $0,11^{* * *}$ & 0,05 & $-0,05$ & $-0,03$ & $-0,08 * *$ \\
\hline \multirow{4}{*}{$\begin{array}{l}\text { Karakteristike GSJ } \\
\text { (nasljedstvo } \\
\text { i lokacija) }\end{array}$} & Nasljedstvo & $-0,11^{* * *}$ & $\mathbf{0 , 0 7 * * *}$ & $0,05^{*}$ & 0,01 & $-0,02$ \\
\hline & Grad Zagreb & 0,00 & $-0,21^{* * *}$ & $-0,05$ & $0,07^{*}$ & $0,19 * * *$ \\
\hline & Primorje & 0,02 & $-0,24^{* * *}$ & $-0,06 * *$ & $0,09 * * *$ & $0,18^{* * *}$ \\
\hline & Središnja HR & 0,00 & $-0,03$ & $-0,08^{* * *}$ & 0,03 & $0,08^{* * *}$ \\
\hline \multirow{9}{*}{$\begin{array}{l}\text { Sociodemografske } \\
\text { karakteristike } \\
\text { referentne osobe }\end{array}$} & Spol (muški) & $-0,02$ & $\mathbf{0 , 0 4} *$ & $-0,03$ & $-0,02$ & 0,02 \\
\hline & Mirovina & $-0,01$ & $-0,09^{* *}$ & 0,02 & 0,00 & $0,09^{* * *}$ \\
\hline & Nezaposlen/neaktivan & 0,05 & 0,02 & $-0,06$ & $-0,01$ & 0,00 \\
\hline & Samozaposlen & $-0,24 * * *$ & 0,06 & $-0,14$ & 0,08 & $0,24^{* * *}$ \\
\hline & $\begin{array}{l}\text { Srednja } \\
\text { stručna sprema }\end{array}$ & $-0,14^{* * *}$ & $-0,06$ & 0,03 & 0,06 & $0,12^{*}$ \\
\hline & $\begin{array}{l}\text { Visoka i viša } \\
\text { stručna sprema }\end{array}$ & $-0,19 * * *$ & $0,13^{* *}$ & 0,05 & 0,08 & $0,20^{* * *}$ \\
\hline & Od 35 do 45 godina & $-0,13 * * *$ & $-0,01$ & 0,04 & 0,05 & 0,05 \\
\hline & Od 45 do 64 godina & $-0,18^{* * *}$ & 0,00 & 0,07 & 0,01 & $\mathbf{0 , 1 1} * *$ \\
\hline & $65+$ godina & $-0,27^{* * *}$ & 0,07 & 0,04 & 0,05 & $0,12^{* *}$ \\
\hline \multirow{2}{*}{$\begin{array}{l}\text { Karakteristike } \\
\text { kućanstva }\end{array}$} & Broj djece u kućanstvu & $0,05^{* * *}$ & 0,02 & 0,00 & $-0,05^{* * *}$ & $-0,01$ \\
\hline & Broj članova kućanstva & $-0,03 * * *$ & $-0,02^{*}$ & 0,00 & $\mathbf{0 , 0 3} * *$ & $0,02 *$ \\
\hline \multirow{2}{*}{$\begin{array}{l}\text { Pokazatelji } \\
\text { zaduženosti }\end{array}$} & Hipotekarni dug za GSJ & $-0,08^{* *}$ & 0,11** & 0,04 & $-0,02$ & $-0,05$ \\
\hline & Potrošački dug & $\mathbf{0 , 0 7 * * *}$ & $-0,03$ & $-0,03$ & 0,03 & $-0,03$ \\
\hline \multirow{2}{*}{$\begin{array}{l}\text { Ostale } \\
\text { karakteristike }\end{array}$} & Primatelj soc. pomoći & $0,07^{* *}$ & 0,02 & $-0,05$ & 0,04 & $-0,08^{*}$ \\
\hline & Sklonost riziku & 0,01 & $-0,08$ & $-0,06$ & 0,02 & $0,10^{* *}$ \\
\hline
\end{tabular}

${ }^{*}$ Generalizirani probit model s utvrđenim redoslijedom alternativa, marginalni efekti.

Napomena: Znakovi ${ }^{* * *},{ }^{* *} i{ }^{*}$ označuju statističku signifikantnost na razini od 99\%, 95\% odnosno 90\%. Referentne kategorije su: za dohodak - dohodak_5kvintilna skupina; za lokaciju GSJ - lokacija_GSJ_Istočna HR; za status na tržištu rada - zaposlen; za stručnu spremu - osnovno obrazovanje ili bez obrazovanja, za godine starosti - do 34 godina starosti. Izvor: AFPK, izračun autorice.

Rezultati procijenjenog modela pokazuju da su informacije o glavnoj stambenoj jedinici signifikantne pri određivanju pozicije kućanstva u distribuciji neto imovine. Tako nasljedstvo nad glavnom stambenom jedinicom smanjuje vjerojatnost da je kućanstvo locirano u najsiromašnijoj kvintilnoj skupini neto imovine (za 11\%) i povećava vjerojatnost da se kućanstvo nalazi u nešto bogatijim kvintilnim skupinama neto imovine (za 2. i 3. kvintilnu skupinu vrijednosti neto imovine). Ipak, nasljedstvo nad glavnom stambenom jedinicom ne utječe na vjerojatnost da se kućanstvo nalazi u najimućnijim kvintilnim skupinama neto imovine, s obzirom na to da rezultati za 4. i 5. kvintilnu skupinu vrijednosti neto imovine nisu statistički značajni za ovu varijablu.

Lokacija glavne stambene jedinice iznimno je bitna za određivanje pozicije kućanstva u distribuciji neto imovine. Nakon što se uzmu u obzir svi ostali činitelji, kućanstva čija je glavna stambena jedinica locirana u Primorju ili Gradu Zagrebu imaju manju vjerojatnost da se nalaze u siromašnijim kvintilnim skupinama neto imovine (2. i 3. kvintilnoj skupini) a veću vjerojatnost da se nalaze u bogatijim kvintilnim skupinama neto imovine (4. ili 5. kvintilnoj skupini) u usporedbi s kućanstvima iz Istočne Hrvatske, koja čine referentnu kategoriju. Ovdje je potrebno istaknuti da 
neovisno o važnom utjecaju geografske lokacije glavne stambene jedinice na poziciju kućanstva unutar distribucije neto imovine, lokacija nema signifikantan utjecaj na vjerojatnost da se kućanstvo nalazi u najsiromašnijoj (1.) kvintilnoj skupini po vrijednosti neto imovine, što je u skladu s prethodno provedenom deskriptivnom analizom gdje je pokazano da većina kućanstava koja se nalazi u najnižoj dohodovnoj kvintilnoj kategoriji po vrijednosti neto imovine ni ne posjeduje glavnu stambenu jedinicu.

Kada je riječ o sociodemografskim karakteristikama, status na tržištu rada samo djelomično utječe na vjerojatnost da se kućanstvo nalazi u određenoj kvintilnoj skupini neto imovine. Tako npr. kućanstva sa samozaposlenim osobama imaju $24 \%$ manju vjerojatnost da se nalaze u najsiromašnijoj kvintilnoj skupini i $23 \%$ veću vjerojatnost da se nalaze u najimućnijoj kvintilnoj skupini neto imovine, u usporedbi s kućanstvima sa zaposlenom referentnom osobom, što je u skladu s nalazima deskriptivne analize koja upućuje na veliku vrijednost imovine od samozapošljavanja i nejednakost u njenoj distribuciji među kućanstvima. Kada je riječ o ostalim kategorijama statusa na tržištu rada, rezultati imaju očekivani predznak ali nisu statistički značajni. Jedina iznimka se odnosi na kućanstva s umirovljenom referentnom sobom, koja imaju $9 \%$ veću vjerojatnost da se nalaze u najvišoj kvintilnoj kategoriji po vrijednosti neto imovine, u odnosu na kućanstva sa zaposlenom referentnom osobom.

Kućanstva s višom razinom obrazovanja i godina starosti referentne osobe imaju veću vjerojatnost da se kućanstvo nalazi u višoj kvintilnoj skupini imovine. Tako npr. visokoobrazovane referentne osobe i one sa srednjoškolskim obrazovanjem imaju (19\% i 14\%) manju vjerojatnost da se nalaze u najsiromašnijoj kvintilnoj skupini, i (20\% i 12\%) veću vjerojatnost da se nalaze u najvišoj kvintilnoj skupini neto imovine u odnosu na referentne osobe s osnovnim obrazovanjem ili bez obrazovanja. Kućanstva sa starijim referentnim osobama (+65) imaju zamjetno manju vjerojatnost da se nalaze u najsiromašnijoj kvintilnoj skupini neto imovine i višu vjerojatnost da se nalaze u najimućnijoj kvintilnoj skupini neto imovine u odnosu na kućanstva gdje referentna osoba ima ispod 35 godina starosti. Sličan efekt, samo nešto umjerenijeg intenziteta potvrđen je i za kućanstva s referentnom osobom zrele dobi (u dobnoj skupini od 45 do 64). Analiza potvrđuje i važnost karakteristika kućanstva za poziciju kućanstva u distribuciji neto imovine, gdje se kućanstva s više djece i manje članova kućanstva imaju veću vjerojatnost da se nalaze u siromašnijim kvintilnim skupinama neto imovine i obrnuto.

Naposljetku, rezultati potvrđuju i da kućanstva koja su prema vlastitoj procjeni spremna na preuzimanje financijskih rizika imaju veću vjerojatnost da se nalaze u najvišoj kvintilnoj kategoriji unutar distribucije neto imovine, dok se kućanstva koja su primatelji socijalne pomoći, kao i kućanstva koja imaju dug, imaju veću vjerojatnost da se nalaze u siromašnijim kvintilnim kategorijama neto imovine (pri čemu kućanstva s potrošačkim dugom imaju veću vjerojatnost da su u najnižoj kvintilnoj kategoriji po vrijednosti neto imovine). 


\section{ZAKLJUČAK}

U ovom radu korištena je anketa o financiranju i potrošnji kućanstava kako bi analizirali distribuciju neto imovine kućanstava i njene glavne komponente. Rezultati pokazuju da postoji umjerena nejednakost $\mathrm{u}$ raspodjeli imovine među kućanstvima u Hrvatskoj. Nejednakost $\mathrm{u}$ posjedovanju financijske imovine mjerena Ginijevim koeficijentom, izraženija je od nejednakosti u posjedovanju realne imovine, s obzirom na to da samo neka kućanstva posjeduju značajne vrijednosti financijske imovine dok je medijalna vrijednost financijske imovine za kućanstvo 500 eura. Realna imovine je široko rasprostranjena među kućanstvima, te $85 \%$ posjeduje glavnu stambenu jedinicu koja predstavlja najveći dio vrijednosti neto imovine kućanstava, medijalne vrijednosti 66 tisuća eura. Vrijednost ukupne neto imovine zamjetno varira među kućanstvima, u ovisnosti o njihovim sociodemografskim karakteristikama, dohotku, vlasništvu nad nekretninom i geografskoj lokaciji unutar koje kućanstvo prebiva.

Rezultati ekonometrijskog modela pokazuju da je pozicija kućanstva unutar distribucije neto imovine određena interakcijom mnogobrojnih faktora. Pri tome se izdvaja važnost glavne stambene jedinice, koja je i najznačajnija komponenta vrijednosti neto imovine, i to njenog načina stjecanja te geografske lokacije. Kućanstva s naslijeđenom glavnom stambenom jedinicom imaju manju vjerojatnost da se nalaze u najnižoj kvintilnoj skupini po vrijednosti neto imovine, dok kućanstva čija je glavna stambene jedinica locirana u Gradu Zagrebu ili u Primorju imaju veću vjerojatnost da se nalaze u višim kvintilnim skupinama neto imovine.

Kućanstva s višom razinom dohotka, obrazovanja i godina starosti referentne osobe imaju veću vjerojatnost da se kućanstvo nalazi u najvišim kvintilnim kategorijama po vrijednosti neto imovine. Isti utjecaj potvrđen je i za preuzimanje financijskog rizika i posjedovanje vlastitog biznisa (samozapošljavanje) koji su se pokazali kao karakteristike povezane s vjerojatnošću da se kućanstvo nalazi u najvišim kvintilnim kategorijama neto imovine. S druge strane, kućanstva s više djece, koja su primatelji socijalne pomoći, sa slabo obrazovanom i mlađom referentnom osobom imaju najveću vjerojatnost da se nalaze u najsiromašnijim kvintilnim kategorijama neto imovine.

Ovaj rad stoga predstavlja prvi pokušaj procjene nejednakosti imovine u Hrvatskoj i čimbenika koji na nju utječu. Neophodna je daljnja usporedba prikupljenih podataka s ostalim anketnim i administrativnim izvorima podataka (Porezne uprave, DZS-a) i nastavak sustavnog prikupljanja podataka o imovini kao i nastavak istraživanja u području nejednakosti raspodjele (imovine), budući da su takve analize uglavnom malobrojne u Hrvatskoj. 


\section{LITERATURA}

1. Arrondel, L., Roger, M. i Savignac, F., 2014. Wealth and income in the euro area Heterogenity in households' behaviour. ECB Working Paper, br. 1709.

2. Auclert, A., 2017. Monetary policy and the redistributional channel. NBER Working Paper, br. 23451. https://doi.org/10.3386/w23451

3. Blanchet, T., Flores, I. i Morgan, M., 2018. The Weight of the Rich: Improving Surveys Using Tax Data. WID.world Working Paper, br. 2018/12.

4. Boes, S., 2006. REGOPROB: Stata module to estimate random effects generalized ordered probit models. Statistical Software Components S456604. Boston: Boston College Department of Economics.

5. Carpantier, J. F., Olivera, J. i Van Kerm, P., 2017. Macroprudential policy and household wealth inequality. Society for the Study of Economic Inequality, Working Paper, ECINEQ WP 2017 - 442.

6. DZS, 2017. Anketa o dohotku stanovništva 2016. Pokazatelji siromaštva i socijalne isključenosti u 2016.

7. Christiaensen, L. [i sur.], 2019. Jobs Challenges in Slavonia, Croatia - A Subnational Labor Market Assessment.World Bank Group, Jobs Working Paper, br. 35. https://doi.org/10.1596/32300

8. HNB, 2016. Financijska stabilnost, br. 16. Zagreb: Hrvatska narodna banka.

9. HNB, 2019. Financijska stabilnost, br. 20. Zagreb: Hrvatska narodna banka.

10. Du Caju, P., 2013. The distribution of household wealth in Belgium: initial findings of the second wave of the Household Finance and Consumption Survey (HFCS). National Bank of Belgium, Economic Review, str. 27-43.

11. ECB, 2013. The eurosystem household finance and consumption survey, Results from the first wave. ECB Statistic Paper Series, br. 2.

12. ECB, 2016. The Household Finance and Consumption Survey: results from the second wave. ECB Statistic Paper, br. 18.

13. ECB, 2016a. The Household Finance and Consumption Survey, Wave 2, Core and derived variables catalog. December 2016.

14. Fessler P., Lindner P. i Schurz M., 2019. Eurosystem Household Finance and Consumption Survey 2017 for Austria. Monetary Policy \& the Economy, Oesterreichische Nationalbank (Austrian Central Bank), Q4(18), str. 36-66.

15. Fessler, P. i Schürz, M., 2015. Private Wealth across European Countries: The role of income, Inheritance and the Welfare State. ECB Working Paper, br. 1847.

16. Fessler, P., Linder, P. i Segalla, E., 2014. Net Wealth Across the Euro Area -Why Household Structure Matters and How to Control for It. ECB Working Paper, br. 1663.

17. Georgakopoulos, I., 2019. Income and Wealth in Malta: Evidence from Micro Data. Central Bank of Malta, br. 3/2019.

18. Green, W. i Hensher, D., 2010. Modeling Ordered Choices. New York: Cambridge University Press. https://doi.org/10.1017/CB09780511845062

19. Hammer, B., 2015. The ownership of assets and the role of age: Agespecific household balance sheets for euro area countries. Ageing Europe, Working Paper, br. 9. 
20. Herceg, I. i Nestić, D., 2014. A New Cluster-Based Financial Vulnerability Indicator and Its Application to Household Stress Testing in Croatia. Emerging markets finance and trade, 50(5), str. 60-77. https://doi.org/10.2753/REE1540-496X500504

21. Herceg, I. i Šošić, V., 2011. The Anatomy of Household in Croatia: Enlisting More Creditworthy Households or Relaxing Lending Standards? Comparative Economic Studies, 53, str. 199-221. https://doi.org/10.3386/w23451

22. Jappelli, T., 1995. Does social security reduce the accumulation of private wealth? Evidence from Italian survey data. Ricerche Economiche, 49, str. 1-31. https://doi.org/10.1016/00355054(95)90008-X

23. Jemrić, I. i Vrbanc, I., 2019. Anketa o financiranju i potrošnji kućanstava. U pripremi.

24. Kontbay-Busun, S. i Peichl, A., 2015. Multidimensional Affluence in Income and Wealth in the Eurozone: A Cross-Country Comparison Using the HFCS. IZA Discussion Paper, br. 9139. https://doi.org/10.2139/ssrn.2562315

25. Leitner, S., 2015. Drivers of Wealth Inequality in Euro Area Countries. The Vienna Institute for International Economic Studies, Working Paper, br. 122.

26. Lise, J., 2011. On-the-Job Search and Precautionary Savings: Theory and Empirics of Earnings and Wealth Inequality. Institute for Fiscal Studies, Working Paper, br. 11/2016. https://doi.org/10.1920/wp.ifs.2011.1116

27. Maestri, V., Bogliacino, F. i Salverda, W., 2014. Wealth Inequality and the Accumulation of Debt. U W. Salverda [i sur.]. Changing Inequalities in Rich Countries: Analytical and Comparative Perspectives. https://doi.org/10.1093/acprof:oso/9780199687435.001.0001

28. Martinez, F. i Uribe, F., 2018. Determinants of Household Position within Chilean Wealth Household's Distribution. Working Papers Central Bank of Chile, br. 827.

29. Mathä, T. J., Porpiglia, A. i Ziegelmeyer, M., 2014. Household wealth in the euro area: The importance of intergenerational transfers, home ownership and house price dynamics. ECB Working Paper, br. 1690. https://doi.org/10.3386/w23451

30. Merikull, J. i Room, T., 2016. The assets, liabilities and wealth of Estonian households: Results of the Household Finance and Consumption Survey. Eesti Pank, Occasional Paper, br. 3/2016. https://doi.org/10.23656/25045520/32016/0007

31. Modigliani, F. i Brumberg, R., 1954. Utility analysis and the Consumption Function: an Interpretation of Cross-section Data. U: K. Kurihara. Post-Keynesian Economics. New Brunswick: Rutgers University Press, str. 388-436.

32. Nestić, D., 2005. Income Distribution in Croatia: What Do the Household Budget Survey Data Tell Us? Financial theory and practice, br. 29(1), str. 39 - 53.

33. Piketty, T., 2011. On the Long-Run Evolution of Inheritance: France 1820 - 2050. The Quarterly Journal of Economics, br. 3(126), str. 1071-1131. https://doi.org/10.1093/qje/qjr020

34. Rosan, M. and Zauder K., 2019.A Micro-level Analysis of Croatian Households' Debt Participation. U pripremi.

35. Rubil, I., 2013. Razlike u siromaštvu na razini regija u Hrvatskoj: uloga razlika u prosječnim dohocima i nejednakostima distribucije dohodaka. Radni materijali EIZ-a, br. 1.

36. Rubil, I., Stubbs, P. i Zrinščak, S., 2018. Child Poverty and Household Coping Strategies in Croatia: A Quantitative-Qualitative Study. Privredna kretanja i ekonomska politika, br. 26(2) (141), str. 59 - 116. https://doi.org/10.15179/pkiep.26.2.2 
37. Sierminska, E. i Medgyesi M., 2013. The distribution of wealth between households. European Commission Research Note, br. 11.

38. Sierminska, E., Frick J. R. i Grabka, M. M., 2010. Examining the gender wealth gap. Oxford Economic Papers, br. 62(4), str. 669-690. https://doi.org/10.1093/oep/gpq007

39. Tkalec, M., Vizek, M. i Žilić, I., 2018. Pregled tržišta nekretnina Republike Hrvatske 2012.-2017., Ekonomski institut, Zagreb.

40. Tzamourani, P., 2019. The interest rate exposure of euro area households. Deutsche Bundesbank Discussion Paper, br. 1/2019. https://doi.org/10.2139/ssrn.3209226

41. Vermeulen, P., 2014. How fat is the top tail of the wealth distribution. ECB Working Paper, br. 1692.

42. Vermeulen, P., 2016. Estimating the top tail of the wealth distribution. ECB Working Paper, br. 1907.

43. Williams, R., 2006. Generalized Ordered Logit/partial Proportional Odds Models for Ordinal Dependent Variables. The Stata Journal, br. 6, str. 58-82. https://doi.org/10.1177/1536867X0600600104

44. Zakon o prodaji stanova nad kojima postoji stanarsko pravo, NN 27/91. Zagreb: Narodne novine.

45. Zakon o socijalnoj skrbi, NN 152/14. Zagreb: Narodne novine.

46. Zucman, G. i Piketty, T., 2015. Wealth and Inheritance in the Long Run. Chapter 15. u: Handbook of Income Distribution. Volume 2B. North Holland, str. 1303-1368. 


\section{DODATAK}

\section{TABLICA 4.}

Usporedba sociodemografskih karakteristika kućanstava*

\begin{tabular}{|c|c|c|c|}
\hline \multicolumn{2}{|c|}{ Informacije o referentnoj osobi } & \multirow{2}{*}{$\begin{array}{c}\text { AFPK } \\
24\end{array}$} & \multirow{2}{*}{$\frac{\text { EU SILC }}{26}$} \\
\hline \multirow{3}{*}{ Obrazovanje } & Osnovno & & \\
\hline & Srednje & 59 & 57 \\
\hline & Visoko & 16 & 17 \\
\hline \multirow{4}{*}{ Dob } & Do 24 & 25 & 26 \\
\hline & $25-54$ & 37 & 41 \\
\hline & $55-64$ & 17 & 14 \\
\hline & $65+$ & 21 & 19 \\
\hline \multirow{4}{*}{ Status na tržištu rada } & Zaposleni & 45 & 38 \\
\hline & Samozaposleni & 3 & 4 \\
\hline & Mirovina & 42 & 31 \\
\hline & Neaktivni/nezaposleni & 9 & 27 \\
\hline \multicolumn{2}{|c|}{ Prosječna veličina kućanstva (br. osoba) } & & 2,8 \\
\hline \multicolumn{4}{|c|}{ Informacije o glavnoj stambenoj jedinici } \\
\hline & Vlasnici & 85 & 90 \\
\hline & Unajmljivači & 15 & 10 \\
\hline
\end{tabular}

*Usporedba Ankete o financijama i potrošnji kućanstva i Ankete o dohotku stanovništva (EU SILC) za 2016.

Napomena: Informacije o referentnoj osobi za AFPK anketu su izračunate koristeći procijenjene pondere i svih 5 verzija imputacije podataka. Informacije o referentnoj osobi za EU-SILC preuzete su iz podataka Eurostata. Izvori: AFPK i Eurostat (EU SILC). 
TABLICA 5.

Ginijev koeficijent za potkomponente realne i financijske imovine

\begin{tabular}{lc} 
Komponente neto imovine & Gini koeficijent \\
\hline Realna imovina & $\mathbf{0 , 5 9}$ \\
\hline Glavna stambena jedinica & 0,56 \\
\hline Ostale nekretnine & 0,93 \\
\hline Vozila & 0,69 \\
\hline Ostale dragocjenosti & 0,99 \\
\hline Imovina od samozapošljavanja & 0,99 \\
\hline Financijska imovina & $\mathbf{0 , 8 8}$ \\
\hline Tekući računi & 0,83 \\
\hline Štedni računi & 0,96 \\
\hline Dobrovoljna mirovina/životno osiguranje & 0,99 \\
\hline Uzajamni fondovi & 0,99 \\
\hline Novac kod kućanstava & 0,99 \\
\hline Dionice & 0,98 \\
\hline Obveznice & 0,99 \\
\hline Ostale vrste financijske imovine & 0,96 \\
\hline Obveze & $\mathbf{0 , 9 0}$ \\
\hline Hipotekarni dug & 0,96 \\
\hline Nehipotekarni dug & 0,89 \\
\hline Ukupni godišnji bruto dohodak & 0,51 \\
\hline Bruto imovina & $\mathbf{0 , 5 9}$ \\
\hline Neto imovina & $\mathbf{0 , 6 1}$ \\
\hline
\end{tabular}

Izvor: AFPK, izračun autorice. 
TABLICA 6.

Vjerojatnost da se kućanstvo nalazi u određenoj kvintilnoj skupini neto imovine* (Provjera robusnosti, alternativne specifikacije modela)

\begin{tabular}{|c|c|c|c|c|c|c|}
\hline & & \multicolumn{5}{|c|}{ Kvintili neto imovine } \\
\hline & & 1 & 2 & 3 & 4 & 5 \\
\hline \multirow{4}{*}{$\begin{array}{l}\text { Dohodak } \\
\text { po kvintilima }\end{array}$} & 1 & $0,13 * * *$ & $0,13 * * *$ & $-0,01$ & $-0,06$ & $-0,18 * * *$ \\
\hline & 2 & $0,16 * * *$ & $0,12 * * *$ & 0,01 & $-0,07$ & $-0,22^{* * *}$ \\
\hline & 3 & $0,10 * * *$ & $0,10 * * *$ & 0,03 & $-0,05$ & $-0,18^{* * *}$ \\
\hline & 4 & 0,06 & 0,05 & 0,03 & $-0,05$ & $-0,10 * *$ \\
\hline \multirow{4}{*}{$\begin{array}{l}\text { Karakteristike GSJ } \\
\text { (nasljedstvo } \\
\text { i lokacija) }\end{array}$} & Nasljedstvo & $-0,11^{* * *}$ & $0,08^{* * *}$ & $0,04^{*}$ & 0,01 & $-0,02$ \\
\hline & Grad Zagreb & 0,00 & $-0,22^{* * *}$ & $-0,04$ & $0,06 *$ & $0,21 * * *$ \\
\hline & Primorje & 0,03 & $-0,24 * * *$ & $-0,07 * *$ & $0,09 * * *$ & $0,18 * * *$ \\
\hline & Središnja HR & 0,00 & $-0,03$ & $-0,08 * *$ & 0,02 & $0,08 * * *$ \\
\hline \multirow{9}{*}{$\begin{array}{l}\text { Sociodemografske } \\
\text { karakteristike } \\
\text { referentne osobe }\end{array}$} & Spol (muški) & $-0,01$ & $0,04^{*}$ & $-0,03$ & $-0,02$ & 0,02 \\
\hline & Mirovina & $-0,02$ & $-0,08^{*}$ & 0,02 & 0,01 & $0,08 * * *$ \\
\hline & Nezaposlen/neaktivan & 0,04 & 0,03 & $-0,05$ & $-0,01$ & $-0,01$ \\
\hline & Samozaposlen & $-0,26 * * *$ & 0,06 & $-0,11$ & 0,08 & $0,23^{* * *}$ \\
\hline & $\begin{array}{l}\text { Srednja } \\
\text { stručna sprema }\end{array}$ & $-0,14^{* * *}$ & $-0,06$ & 0,03 & 0,06 & 0,10 \\
\hline & $\begin{array}{l}\text { Visoka i viša } \\
\text { stručna sprema }\end{array}$ & $-0,17 * * *$ & $0,11^{* *}$ & 0,03 & 0,07 & $0,18^{* * *}$ \\
\hline & Od 35 do 45 godina & $-0,13^{* * *}$ & $-0,02$ & 0,04 & 0,05 & 0,06 \\
\hline & Od 45 do 64 godina & $-0,18 * * *$ & $-0,01$ & 0,06 & 0,01 & $0,12^{* *}$ \\
\hline & $65+$ godina & $-0,27^{* * *}$ & 0,06 & 0,04 & 0,05 & $0,13 * *$ \\
\hline \multirow{2}{*}{$\begin{array}{l}\text { Karakteristike } \\
\text { kućanstva }\end{array}$} & Broj djece u kućanstvu & $0,05^{* * *}$ & 0,03 & $-0,01$ & $-0,05^{* * *}$ & $-0,02$ \\
\hline & Broj članova kućanstva & $-0,04 * * *$ & $-0,03 * * *$ & 0,00 & $0,03 * * *$ & $0,05^{* * *}$ \\
\hline \multirow{2}{*}{$\begin{array}{l}\text { Pokazatelji } \\
\text { zaduženosti }\end{array}$} & Hipotekarni dug za GSJ & $-0,08^{*}$ & $0,10 * *$ & 0,05 & $-0,03$ & $-0,06$ \\
\hline & Potrošački dug & $0,07^{* * *}$ & $-0,02$ & $-0,04$ & 0,03 & $-0,03$ \\
\hline \multirow{2}{*}{$\begin{array}{l}\text { Ostale } \\
\text { karakteristike }\end{array}$} & Primatelj soc. pomoći & $0,07 * *$ & 0,02 & $-0,05$ & 0,03 & $-0,07^{*}$ \\
\hline & Sklonost riziku & 0,02 & $-0,07$ & $-0,05$ & 0,01 & 0,09* \\
\hline
\end{tabular}

*Generalizirani probit model s utvrđenim redoslijedom alternativa, marginalni efekti, kvintilne skupine dohotka normalizirane za broj članova kućanstva prema OECD-ovoj skali korekcije.

Napomena: Znakovi ***, ** $i^{*}$ označuju statističku signifikantnost na razini od 99\%, 95\% odnosno 90\%.

Referentne kategorije su: za dohodak - dohodak_5kvintilna skupina; za lokaciju GSJ - lokacija_GSJ_Istočna HR; za status na tržištu rada - zaposlen; za stručnu spremu - osnovno obrazovanje ili bez obrazovanja, za godine starosti - do 34 godina starosti. Izvor: AFPK, izračun autorice. 
TABLICA 7.

Vjerojatnost da se kućanstvo nalazi u određenoj kvintilnoj skupini neto imovine*

\begin{tabular}{|c|c|c|c|c|c|c|}
\hline & & \multicolumn{5}{|c|}{ Kvintili neto imovine } \\
\hline & & 1 & 2 & 3 & 4 & 5 \\
\hline \multirow{4}{*}{$\begin{array}{l}\text { Dohodak } \\
\text { po kvintilima } \\
>1300 \text { eura }\end{array}$} & 1 & $0,28 * * *$ & 0,07 & $-0,01$ & $-0,08$ & $-0,26 * * *$ \\
\hline & 2 & $0,18^{* * *}$ & 0,06 & $-0,03$ & $-0,03$ & $-0,25^{* * *}$ \\
\hline & 3 & $0,14 * * *$ & $0,09 * *$ & $-0,01$ & $-0,04$ & $-0,18 * * *$ \\
\hline & 4 & $0,13^{* * *}$ & 0,02 & $-0,05$ & $-0,02$ & $-0,09 *$ \\
\hline \multirow{4}{*}{$\begin{array}{l}\text { Karakteristike GSJ } \\
\text { (nasljedstvo } \\
\text { i lokacija) }\end{array}$} & Nasljedstvo & $-0,15^{* * *}$ & $0,12 * * *$ & 0,04 & 0,00 & $-0,02$ \\
\hline & Grad Zagreb & 0,05 & $-0,25^{* * *}$ & $-0,06$ & $0,06^{*}$ & $0,20 * * *$ \\
\hline & Primorje & 0,04 & $-0,27^{* * *}$ & $-0,06^{*}$ & $\mathbf{0 , 1 1} * * *$ & $0,18 * * *$ \\
\hline & Središnja HR & 0,00 & $-0,04$ & $-0,08^{* *}$ & $0,06 *$ & $0,06 * *$ \\
\hline \multirow{9}{*}{$\begin{array}{l}\text { Sociodemografske } \\
\text { karakteristike } \\
\text { referentne osobe }\end{array}$} & Spol (muški) & $-0,01$ & 0,04 & $-0,03$ & $-0,03$ & 0,02 \\
\hline & Mirovina & $-0,02$ & $-0,03$ & $-0,01$ & $-0,01$ & $0,08 * *$ \\
\hline & Nezaposlen/neaktivan & 0,01 & 0,02 & $-0,01$ & 0,00 & $-0,01$ \\
\hline & Samozaposlen & $-0,97$ & 0,79 & $-0,11$ & 0,04 & $0,25 * * *$ \\
\hline & $\begin{array}{l}\text { Srednja } \\
\text { stručna sprema }\end{array}$ & $-0,13^{* * *}$ & $-0,08$ & 0,05 & 0,01 & 0,15 \\
\hline & $\begin{array}{l}\text { Visoka i viša } \\
\text { stručna sprema }\end{array}$ & $-0,12^{* * *}$ & $-0,20 * * *$ & 0,08 & 0,02 & $0,22 *$ \\
\hline & Od 35 do 45 godina & $-0,16^{* * *}$ & 0,06 & 0,00 & 0,04 & 0,06 \\
\hline & Od 45 do 64 godina & $-0,20 * * *$ & 0,02 & 0,04 & 0,03 & $0,12 * *$ \\
\hline & $65+$ godina & $-0,32 * * *$ & $0,11 *$ & 0,03 & 0,05 & $0,13 * *$ \\
\hline \multirow{2}{*}{$\begin{array}{l}\text { Karakteristike } \\
\text { kućanstva }\end{array}$} & Broj djece u kućanstvu & $0,04^{* *}$ & $0,04^{*}$ & $-0,01$ & $-0,05^{* *}$ & $-0,02$ \\
\hline & Broj članova kućanstva & $-0,02$ & $-0,04^{* *}$ & 0,00 & $0,03 * *$ & $0,02 *$ \\
\hline \multirow{2}{*}{$\begin{array}{l}\text { Pokazatelji } \\
\text { zaduženosti }\end{array}$} & Hipotekarni dug za GSJ & $-0,07^{*}$ & $0,14 * * *$ & 0,03 & $-0,04$ & $-0,06$ \\
\hline & Potrošački dug & $0,08 * * *$ & $-0,04$ & $-0,03$ & 0,02 & $-0,03$ \\
\hline \multirow{2}{*}{$\begin{array}{l}\text { Ostale } \\
\text { karakteristike }\end{array}$} & Primatelj soc. pomoći & $0,07^{* *}$ & 0,03 & $-0,08^{*}$ & 0,05 & $-0,07$ \\
\hline & Sklonost riziku & $-0,04$ & $-0,07$ & $-0,03$ & 0,06 & 0,08 \\
\hline
\end{tabular}

*Generalizirani probit model s utvrđenim redoslijedom alternativa, marginalni efekti, uzorak reduciran za kućanstva koja su prijavila bruto godišnje dohotke ispod 1300 eura, te sukladno s time modificirane kvintilne skupine neto imovine i dohotka. Napomena: Znakovi ***, ** $i^{*}$ označuju statističku signifikantnost na razini od 99\%, 95\% odnosno 90\%.

Referentne kategorije su: za dohodak - dohodak_5kvintilna skupina; za lokaciju GSJ - lokacija_GSJ_Istočna HR; za status na tržištu rada - zaposlen; za stručnu spremu - osnovno obrazovanje ili bez obrazovanja, za godine starosti - do 34 godina starosti. Izvor: AFPK, izračun autorice. 
TABLICA 8.

Procjenitelj najmanjih kvadrata (Model 1 i 2) i probit s utvrđenim redoslijedom alternativa

\begin{tabular}{|c|c|c|c|c|}
\hline & & OLS (Model 1) & OLS (Model 2) & $\begin{array}{l}\text { Standardizirani } \\
\text { probit s utvrđenim } \\
\text { redoslijedom } \\
\text { alternativa (Model 3) }\end{array}$ \\
\hline \multirow{6}{*}{$\begin{array}{l}\text { Dohodak po } \\
\text { kvintilima (OECD) }\end{array}$} & 1 & $-0,78^{* * *}$ & & $-0,71^{* * *}$ \\
\hline & 2 & $-1,16^{* * *}$ & & $-0,88^{* * *}$ \\
\hline & 3 & $-0,69 * * *$ & & $-0,64^{* * *}$ \\
\hline & 4 & $-0,41^{* *}$ & & $-0,39 * * *$ \\
\hline & $\begin{array}{l}\log \text { (bruto } \\
\text { godišnji dohodak) }\end{array}$ & & $-0,39 * * *$ & \\
\hline & $\begin{array}{l}\log (\text { bruto } \\
\text { godišnji dohodak)^2 }\end{array}$ & & $\mathbf{0 , 0 4} 4^{* * *}$ & \\
\hline \multirow{4}{*}{$\begin{array}{l}\text { Karakteristike GSJ } \\
\text { (Nasljedstvo i } \\
\text { Lokacija) }\end{array}$} & Nasljedstvo & $0,55^{* * *}$ & $0,55^{* * *}$ & $0,15^{* *}$ \\
\hline & Grad Zagreb & $0,50^{* *}$ & $0,54^{* * *}$ & $0,61^{* * *}$ \\
\hline & Primorje & $0,38 * *$ & $0,40^{* *}$ & $0,53^{* * *}$ \\
\hline & Središnja HR & 0,23 & 0,24 & $0,15^{*}$ \\
\hline \multirow{10}{*}{$\begin{array}{l}\text { Sociodemografske } \\
\text { karakteristike } \\
\text { referentne osobe }\end{array}$} & Spol (muški) & 0,06 & 0,07 & 0,03 \\
\hline & Mirovina & $\mathbf{0 , 4 8 * *}$ & 0,23 & $0,29 * * *$ \\
\hline & Nezaposlen/neaktivan & $-0,45^{* *}$ & $-0,42^{*}$ & $-0,12$ \\
\hline & Samozaposlen & $1,03^{* * *}$ & $1,02^{* * *}$ & $0,97^{* * *}$ \\
\hline & Srednja stručna sprema & $0,59 * *$ & $0,77^{* * *}$ & $0,50 * * *$ \\
\hline & $\begin{array}{l}\text { Visoka i viša } \\
\text { stručna sprema }\end{array}$ & $\mathbf{0 , 8 1 * *}$ & $1,03^{* * *}$ & $0,75^{* * *}$ \\
\hline & Od 35 do 45 godina & $0,75^{* * *}$ & & $0,48^{* * *}$ \\
\hline & Od 45 do 64 godina & $0,97^{* * *}$ & & $0,69 * * *$ \\
\hline & $65+$ godina & $1,06^{* * *}$ & & $\mathbf{0 , 8 1 * * *}$ \\
\hline & $\log$ (godine) & & $1,21^{* * *}$ & \\
\hline \multirow{2}{*}{$\begin{array}{l}\text { Karakteristike } \\
\text { kućanstva }\end{array}$} & Broj djece u kućanstvu & $-0,27 * *$ & $-0,25^{* *}$ & $-0,18^{* * *}$ \\
\hline & Broj članova kućanstva & $0,33^{* * *}$ & $0,26^{* * *}$ & $0,22^{* * *}$ \\
\hline \multirow{2}{*}{$\begin{array}{l}\text { Pokazatelji } \\
\text { zaduženosti }\end{array}$} & Hipotekarni dug za GSJ & 0,24 & 0,24 & 0,02 \\
\hline & Potrošački dug & 0,15 & 0,18 & $-0,17^{* *}$ \\
\hline \multirow{3}{*}{$\begin{array}{l}\text { Ostale } \\
\text { karakteristike }\end{array}$} & Primatelj soc. pomoći & $-0,57^{* *}$ & $-0,52^{* *}$ & $-0,23^{* *}$ \\
\hline & Sklonost riziku & 0,37 & $\mathbf{0 , 5 4} *$ & 0,16 \\
\hline & Konstanta & 8,44 & 3,96 & 0,16 \\
\hline \multirow{2}{*}{$\begin{array}{l}\text { Waldow test } \\
\text { homogenosti } \\
\text { koeficijenata }\end{array}$} & chi2 & & & 219,84 \\
\hline & Prob>chi2 & & & 0,000 \\
\hline
\end{tabular}

Napomena: Model 2 procjenitelja najmanjih kvadrata uključuje i kvadrat dohotka zbog nelinearnog utjecaja te varijable. Model 3 predstavlja standardni probit model s utvrđenim redoslijedom alternativa (homogeni koeficijent za različite kategorije zavisne varijable). Rezultati Modela 3 prikazuju procijenjene koeficijente modela a ne marginalne efekte. Prikazani su i rezultati Waldovog testa koji odbija pretpostavku homogenosti (engl. parallel line assumption test).

Izvor: AFPK, izračun autorice. 